\title{
Can Carbon Sequestration in Tasmanian "Wet" Eucalypt Forests Be Used to Mitigate Climate Change? Forest Succession, the Buffering Effects of Soils, and Landscape Processes Must Be Taken into Account
}

\author{
Peter D. McIntosh (D), ${ }^{1}$ James L. Hardcastle, ${ }^{2}$ Tobias Klöffel, ${ }^{3}$ Martin Moroni, ${ }^{4}$ \\ and Talitha C. Santini ${ }^{5}$ \\ ${ }^{1}$ Forest Practices Authority, 30 Patrick Street, Hobart, TAS 7000, Australia \\ ${ }^{2}$ School of Earth and Environmental Sciences, University of Queensland, Brisbane, QLD 4072, Australia \\ ${ }^{3}$ Research Department of Ecology and Ecosystem Management, Technical University of Munich, Freising, Germany \\ ${ }^{4}$ Private Forests Tasmania, 30 Patrick Street, Hobart, TAS 7000, Australia \\ ${ }^{5}$ UWA School of Agriculture and Environment, University of Western Australia, Crawley, WA 6009, Australia
}

Correspondence should be addressed to Peter D. McIntosh; peter.mcintosh@fpa.tas.gov.au

Received 11 November 2019; Revised 25 February 2020; Accepted 28 March 2020; Published 30 July 2020

Academic Editor: Kurt Johnsen

Copyright (c) 2020 Peter D. McIntosh et al. This is an open access article distributed under the Creative Commons Attribution License, which permits unrestricted use, distribution, and reproduction in any medium, provided the original work is properly cited.

\begin{abstract}
Small areas of the wetter parts of southeast Australia including Tasmania support high-biomass "wet" eucalypt forests, including "mixed" forests consisting of mature eucalypts up to $100 \mathrm{~m}$ high with a rainforest understorey. In Tasmania, mixed forests transition to lower biomass rainforests over time. In the scientific and public debate on ways to mitigate climate change, these forests have received attention for their ability to store large amounts of carbon (C), but the contribution of soil C stocks to the total $\mathrm{C}$ in these two ecosystems has not been systematically researched, and consequently, the potential of wet eucalypt forests to serve as long-term $\mathrm{C}$ sinks is uncertain. This study compared soil $\mathrm{C}$ stocks to $1 \mathrm{~m}$ depth at paired sites under rainforest and mixed forests and found that there was no detectable difference of mean total soil $\mathrm{C}$ between the two forest types, and on average, both contained about $200 \mathrm{Mg} \cdot \mathrm{ha}^{-1}$ of C. Some C in subsoil under rainforests is 3000 years old and retains a chemical signature of pyrogenic $\mathrm{C}$, detectable in NMR spectra, indicating that soil $\mathrm{C}$ stocks are buffered against the effects of forest succession. The mean loss of $\mathrm{C}$ in biomass as mixed forests transition to rainforests is estimated to be about $260 \mathrm{Mg} \cdot \mathrm{ha}^{-1}$ over a c. 400 -year period, so the mature mixed forest ecosystem emits about $0.65 \mathrm{Mg} \mathrm{ha}^{-1} \cdot \mathrm{yr}^{-1}$ of $\mathrm{C}$ during its transition to rainforest. For this reason and because of the risk of forest fires, setting aside large areas of wet eucalypt forests as reserves in order to increase landscape $\mathrm{C}$ storage is not a sound strategy for long-term climate change mitigation. Maintaining a mosaic of managed native forests, including regenerating eucalypts, mixed forests, rainforests, and reserves, is likely to be the best strategy for maintaining landscape $\mathrm{C}$ stocks.
\end{abstract}

\section{Introduction}

Natural forest ecosystems contain about $1500 \mathrm{Pg}$ of carbon (C) [1], and on a worldwide basis, forest soils contain about twice the $\mathrm{C}$ of the vegetation they support [2]. The proportions of $\mathrm{C}$ in vegetation and soil varies greatly depending on latitude, altitude, vegetation, climate, and soil [2-4], but in boreal and temperate forests, the average $\mathrm{C}$ content of soils and biomass is about equal $\left(120 \mathrm{Mg} \cdot \mathrm{ha}^{-1}\right)$ [5]. Australian forests as a whole contain the lowest forest biomass and soil C for midlatitudes (mean C of $45 \mathrm{Mg} \cdot \mathrm{ha}^{-1}$ for forests and $83 \mathrm{Mg} \cdot \mathrm{ha}^{-1}$ for soils to $1 \mathrm{~m}$ depth) [2] because of climatic limitations and the relative infertility of large areas of forestsupporting soils. However, the natural forests of Australia's wet southeast include the tallest hardwoods in the world (up to $100 \mathrm{~m}$ high) (Figure 1), and according to some authors 


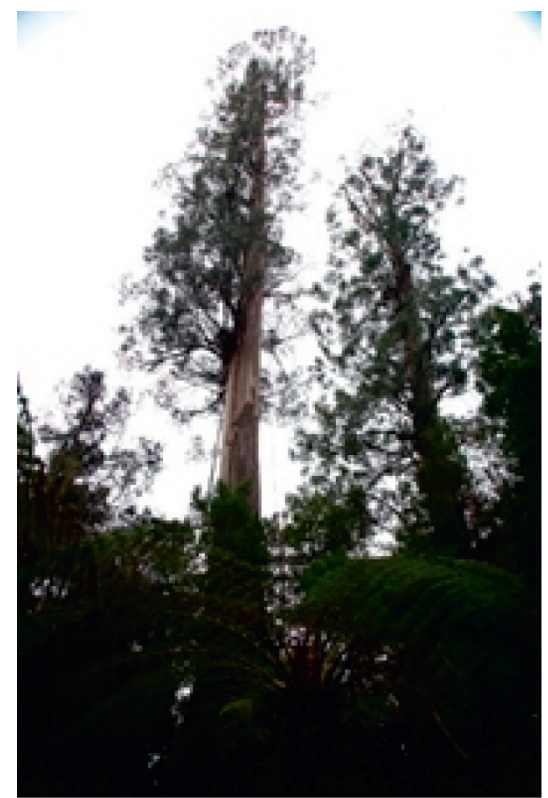

(a)

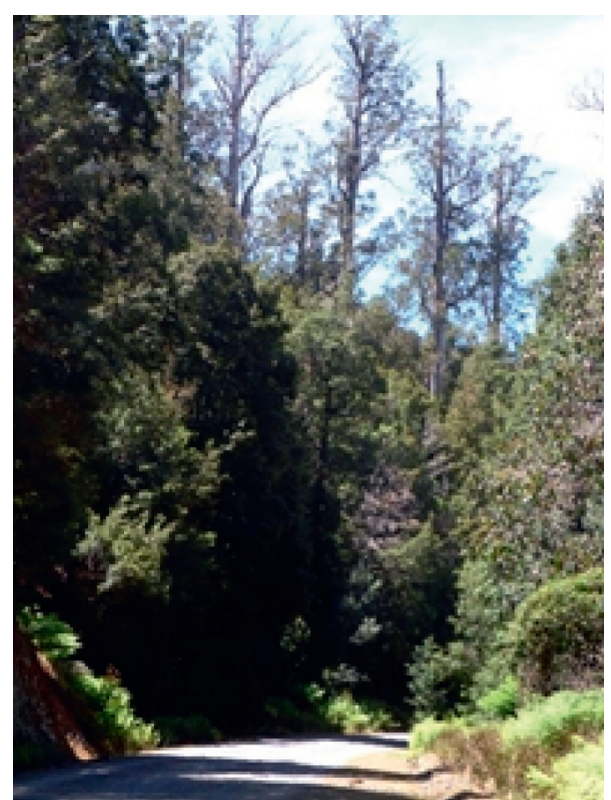

(b)

Figure 1: Iconic Tasmanian wet eucalypt forests. The tree on the left (a) is $100 \mathrm{~m}$ tall. The right-hand side image (b) shows mixed forest consisting of mature tall eucalypts (Eucalyptus regnans) and a dense understorey of rainforest species which are about half as tall as the dominant eucalypts.

(e.g., Keith et al. [6]), the aboveground $\mathrm{C}$ content of these ecosystems is over $2500 \mathrm{Mg} \cdot \mathrm{ha}^{-1}$, which is over 50 times the

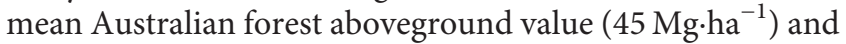
also greatly exceeds mean values for other midlatitude forests (range 32-114 Mg.ha ${ }^{-1}$; [2]), the IPCC figure (96 Mg.ha ${ }^{-1}$; [8]) for biomass $\mathrm{C}$ in world temperate forests, and the mean aboveground $\mathrm{C}$ for mountain ash (Eucalyptus regnans) forests in Victoria (246 Mg.ha ${ }^{-1}$; [7]). However, Sillett et al. [9] found that aboveground biomass $\mathrm{C}$ in forests similar to those described by Keith et al. [6] was at most $706 \mathrm{Mg} \cdot \mathrm{ha}^{-1}$, but probably lower $\left(438 \mathrm{Mg} \cdot \mathrm{ha}^{-1}\right)$ due to the loss of mass in decayed hollow trunks and limbs, and questioned the assertion that the tallest southeast Australian eucalypt forests are the most C-dense forests in the world, quoting measurements of North American redwood ( $\mathrm{Se}$ quoia sempervirens) forests which contain more than $2000 \mathrm{Mg} \cdot \mathrm{ha}^{-1}$ of biomass C.

A typical value for biomass $\mathrm{C}$ (including roots) for Tasmanian mature eucalypt forests $>55 \mathrm{~m}$ high, with $>40 \%$ crown cover (Class 1 forests in the Tasmanian classification), was obtained by Moroni et al. [10]: these contain $470 \mathrm{Mg} \cdot \mathrm{ha}^{-1}$ of C. If all forests supporting all mature trees $>55 \mathrm{~m}$ are included (i.e., all Class 1 and 2 forests), the figure is lower (387 Mg.ha ${ }^{-1}$ ) which is close to the $378 \mathrm{Mg} \cdot \mathrm{ha}^{-1}$ figure obtained by Moroni et al. [11] in a 14-site paired comparison of aboveground biomass (trees and coarse woody debris, but not litter) under mixed forests and rainforest but four times the IPCC figure for biomass $\mathrm{C}$ in world temperate forests $\left(96 \mathrm{Mg} \cdot \mathrm{ha}^{-1}[8]\right)$. The mean figure for $\mathrm{C}$ in all mature Tasmanian "wet" eucalypt forests (those with a dense understorey of shrubs and/or rainforest trees) is $232 \mathrm{Mg} \cdot \mathrm{ha}^{-1}[10]$.
In the northern hemisphere, it has been found that temperate old-growth forests continue to accumulate $\mathrm{C}$ as they mature [12-14] and protection of old-growth temperate forests has been promoted as a $\mathrm{C}$ sequestration policy. A similar policy has been argued for wet eucalypt forests of southeast Australia, in order to moderate climate change induced by the effects of increased concentrations of $\mathrm{CO}_{2}$ in the atmosphere. For example, Mackey et al. ([15], p. 39), in reference to eucalypt forests, proposed that "the remaining intact natural forests constitute a significant standing stock of $\mathrm{C}$ that should be protected from carbon-emitting land-use activities." However, although C stocks will undoubtedly increase as young trees mature, such a policy ignores the fact that old-growth eucalypt forests in Tasmania are not the end point of forest succession [11] and that all eucalypt forests are highly susceptible to fire.

Provided there is no stand-destroying fire and there is a seed source nearby (for example, in a rainforest-dominated gully, on a shady slope, or in a nearby unburned patch of forest), wet eucalypt forests will transition to rainforests, a process described in the classic paper by Gilbert [16]. After fire, a eucalypt forest will normally establish rapidly. By the time the eucalypt forests are about 100 years old, shadetolerant rainforest species may already be established in the understorey. As the eucalypts reach maturity, the rainforest will form a continuous understorey and a "mixed" tall eucalypt/rainforest results ([16], Figure 1.10). The eucalypts cannot regenerate under the rainforest canopy; hence, once the eucalypts reach their maximum age of 300-500 years and progressively die, they are replaced by the rainforest understorey, although eucalypt woody debris may persist for up to two centuries on the forest floor. Peak aboveground 
wood volumes occur when the eucalypts are tallest and contain an understorey of rainforest species (Figure 1). Rainforests, on average, contain about $45 \%$ of the aboveground wood volume and biomass $\mathrm{C}$ of mixed forest [11]. To halt the progression to rainforests and maintain eucalypt cover, fire must return before the eucalypt overstorey (the eucalypt seed source) dies [16, 17].

When considering $\mathrm{C}$ trends in Tasmanian forests, an important question to ask is whether the lower biomass $\mathrm{C}$ in rainforest than in mixed mature eucalypt forest also indicates lower $\mathrm{C}$ in the total ecosystem under rainforest. The answer to this question depends on soil C content, does it change with vegetation cover or does it remain the same? This unanswered question prompted Norris et al. [18] to comment that "the uncertainty around soil carbon represents a priority for further work." One might assume that as mixed forests contain about twice the biomass of rainforests [11], they should return more biomass to the forest floor than rainforests and thus accumulate more soil $\mathrm{C}$ than soils under rainforest. Alternatively, one could argue that frequent fires in eucalypt forests deplete soil C stocks, negating any soil $\mathrm{C}$ increase caused by greater cycling of $\mathrm{C}$ to the forest floor by the maturing eucalypts of greater biomass. A complicating issue can be the accumulation of pyrogenic $\mathrm{C}$ in soils under fire-susceptible forests $[19,20]$.

Previous work on soil C under eucalypts and rainforest in Tasmania has been limited to soil profile analysis undertaken in soil surveys covering a range of soils and parent material and forest types [21-23], supplemented by two additional profiles ([24]; P. D. McIntosh, unpublished data). The surveys were not specifically designed to compare amounts of soil $\mathrm{C}$ under different vegetation types but contain sufficient information to enable soil $\mathrm{C}$ to $1 \mathrm{~m}$ depth under different forest types to be calculated (Table 1). Wet eucalypt forest soils contain about $50 \%$ more $\mathrm{C}$ to $1 \mathrm{~m}$ depth than dry forests, and rainforest soils contain about $50 \%$ more $\mathrm{C}$ than wet forests (Table 1). However, the mean rainforest soil C figure (226 Mg.ha ${ }^{-1}$ ) and the $\mathrm{C} / \mathrm{N}$ ratio of 19 for soil to $1 \mathrm{~m}$ depth under this forest type are based on analysis of only three profiles in northeast Tasmania and cannot be regarded as typical. The highest mean $\mathrm{C} / \mathrm{N}$ ratio (24) is found in soils under dry forests, which experience frequent understorey fires [25], and in which, charcoal is generally visible on the soil surface and in topsoils. Rainforest sites, which have probably not been burnt for at least 500 years, have topsoil $\mathrm{C} / \mathrm{N}$ ratios of 15 , probably a result of higher proportion of microbial residues in relation to plant remains than in topsoils under eucalypts. About half the total soil C to $1 \mathrm{~m}$ depth is held below $30 \mathrm{~cm}$ depth.

Interestingly, the mean figure of $123 \mathrm{Mg} \cdot \mathrm{ha}^{-1}$ for soil C to $1 \mathrm{~m}$ depth under all eucalypt forests in Tasmania over a range of soil types (Table 1) is indistinguishable from the IPCC default figure of $122{\mathrm{Mg} \cdot h a^{-1}}_{\text {[8] for all temperate }}$ forests, higher than the "typical" temperate forest soil figure of $100 \mathrm{Mg} \cdot \mathrm{ha}^{-1}$ by Lal and Lorenz [4] but lower than the c. $150 \mathrm{Mg} \cdot \mathrm{ha}^{-1}$ figure for temperate broadleaf forests studied by Duarte-Guardia et al. ([26], Figure 5(d)). Previous estimates of the soil C pool in forest soils of Tasmania and mainland southeast Australia under different vegetation types by Mackey et al. ([15], p. 28), Dean and WardellJohnson [27], and May et al. [28]) did not take into account published data and exceeded the figures summarised in Table 1 by factors of up to 3.5 [29].

Fedrigo et al. [30] were the first to compare measured soil $\mathrm{C}$ in nearby rainforest, mixed rainforest-wet sclerophyll stands ("ecotone forest"), and wet sclerophyll forest ("eucalypt forest") in the Yarra Ranges of Victoria, but only to $30 \mathrm{~cm}$ depth. They found no significant difference of soil $\mathrm{C}$ between these forest types: values were $163 \mathrm{Mg} \cdot \mathrm{ha}^{-1}$ under wet sclerophyll forest and $149 \mathrm{Mg} \cdot \mathrm{ha}^{-1}$ under rainforest. Unfortunately, no information was provided on whether soils were closely matched across different vegetation plots. Consequently, effects of vegetation or fire on soil C storage may have been conflated with those resulting from inherent soil differences such as depth, drainage, and parent material.

As the information summarised in Table 1 and in the literature is insufficient to answer the question of whether soil C increases, decreases, or remains the same as wet eucalypt forests transition to rainforest over time, a study was undertaken to measure soil $\mathrm{C}$ in paired sites under mixed forest and rainforest in Tasmania. This paper presents the new soil $\mathrm{C}$ data obtained in this study. It also discusses the ecological processes affecting total ecosystem $\mathrm{C}$ and assesses the value of wet eucalypt forests in Tasmania for mitigating the effects of $\mathrm{CO}_{2}$ emissions on climate.

\section{Methods}

2.1. Site Selection. At 14 site pairs, Moroni et al. [11] compared aboveground $\mathrm{C}$ stocks in mixed forests and rainforests representative of mature Tasmanian forest ecosystems. (Mixed forest is defined as a forest of dominant mature eucalypts (e.g., Eucalyptus obliqua, E. regnans, E. delegatensis, E. globulus, and E. viminalis) generally 40-100 m high with a rainforest understorey; rainforest lacks standing eucalypts and the canopy is dominated by species such as Nothofagus cunninghamii, Atherosperma moschatum, and Phyllocladus aspleniifolius.) These forest pairs provided a framework for a soil $\mathrm{C}$ comparison. In a desktop study, all 14 pairs were examined to establish which were best matched with respect to landform, slope, aspect, elevation, and geology. For a short list of pairs, these attributes, together with soil depth and stoniness, were field checked. Six pairs showing least difference between these basic soil physical attributes and which were nonstony or contained only a few stones, and which covered representative areas of mixed eucalypt forest in Tasmania and widespread soil parent rocks, were selected. A seventh mixed forest/rainforest pair, not studied by Moroni et al. [11], was selected using the same site criteria, to provide information on a soil developed on Precambrian siltstone, a rock type extensive in northwest Tasmania. No site had evidence of human-induced soil disturbance or vegetation disturbance in the form of recent fires or clearfelling. Site locations are shown in Figure 2, and brief site details are shown in Table 2. 
TABLE 1: Mean carbon and nitrogen to $1 \mathrm{~m}$ depth for three Tasmanian forest types ${ }^{1,2}$.

\begin{tabular}{|c|c|c|c|c|c|c|}
\hline \multirow{2}{*}{ Forest type } & \multirow{2}{*}{$\begin{array}{l}\text { Analyses to } 0-30 \mathrm{~cm} \text { depth } \\
\text { C }\left(\mathrm{Mg} \cdot \mathrm{ha}^{-1}\right)\end{array}$} & \multicolumn{4}{|c|}{ Analyses to $1 \mathrm{~m}$ depth } & \multirow{2}{*}{$\begin{array}{l}\text { A1 horizon only } \\
\mathrm{C} / \mathrm{N} \text { ratio }\end{array}$} \\
\hline & & $\mathrm{C}\left(\mathrm{Mg} \cdot \mathrm{ha}^{-1}\right)$ & Range $\left(\mathrm{Mg} \cdot \mathrm{ha}^{-1}\right)$ & $\mathrm{N}\left(\mathrm{Mg} \cdot \mathrm{ha}^{-1}\right)$ & $\mathrm{C} / \mathrm{N}$ ratio & \\
\hline Rainforest $(n=3)$ & 102 & 226 & $144-321$ & 11.9 & 19 & 15 \\
\hline Wet eucalypt forest $(n=19)$ & 71 & 147 & $37-273$ & 9.9 & 15 & 22 \\
\hline Dry eucalypt forest ${ }^{3}(n=14)$ & 53 & 92 & $45-168$ & 4.1 & 22 & 24 \\
\hline All eucalypt forests $(n=33)$ & 63 & 123 & & & & \\
\hline
\end{tabular}

${ }^{1}$ From the profile data of Grant et al. [21], Hill et al. [22], Laffan et al. [23], McIntosh [24], and P.D. McIntosh (unpublished data). ${ }^{2}$ Means are arithmetical and not area-weighted. ${ }^{3}$ Generally an overstorey of drought-tolerant species such as Eucalyptus amygdalina, E. globulus, E. viminalis, E. globulus, or E. tenuiramis with a heathy or grassy open understorey.

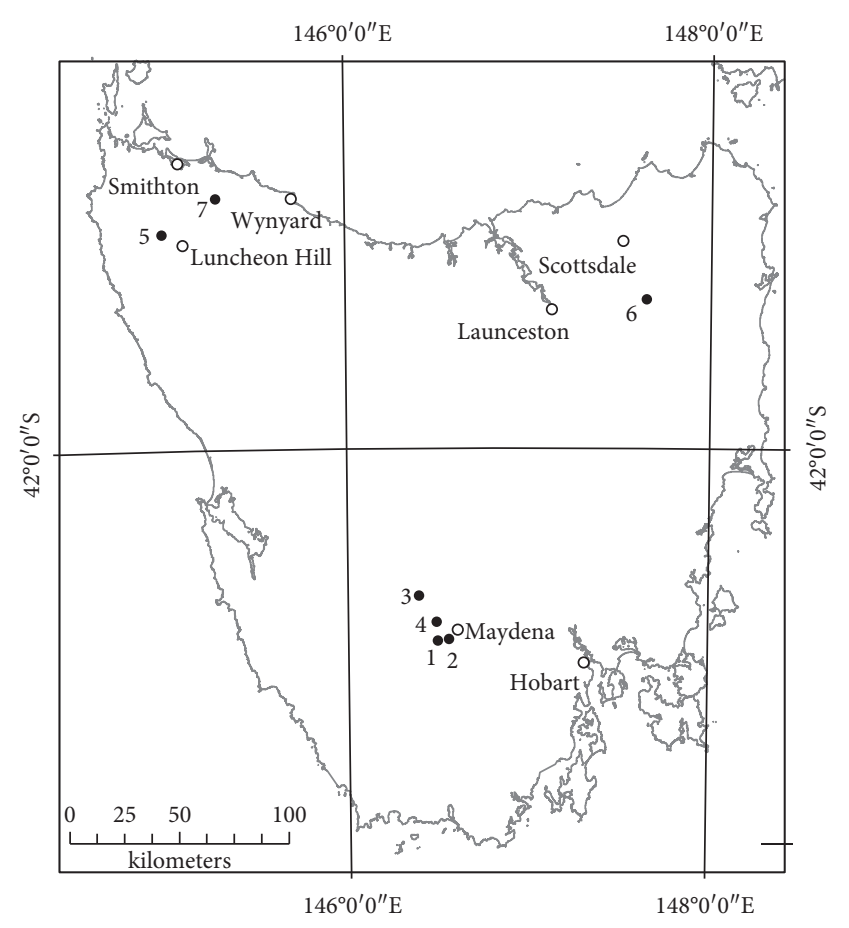

FIgURE 2: Site locations. For site names, see Table 2.

2.2. Field Sampling. Mäkipää et al. [34] and Muukkonen [35] recognised that in boreal forests, 10-20 samples per plot or more are required in order to reasonably estimate amounts of topsoil C on an area basis, and Cunningham et al. [36] recommended at least 30 samples for accurate determination of topsoil C (0-30 cm depth) in plantations on ex-farmland in Victoria, Australia. In practice, ideal sampling strategies such as the mechanised site sampling designed for flat land in New South Wales [37] are usually modified for logistical reasons (e.g., sampling in steep country, manual transport of samples, and time and resources available). For example, despite their earlier studies, Mäkipää et al. [34] and Muukkonen et al. [35] recommended only four samples per plot in their design for soil $\mathrm{C}$ assessment in Tanzania. McKenzie et al. [38] recommended at least four topsoil replicates per site for soil $\mathrm{C}$ assessment in Australia but gave no guidance for subsoil sampling intensity. In a national survey of topsoil C in Australia [39] designed for C accounting purposes, 10 topsoil replicates were taken at each site, at each of 3 depths $(0-10 \mathrm{~cm}, 10-20 \mathrm{~cm}$, and $20-30 \mathrm{~cm})$, and samples were bulked for each depth increment. An identical sampling approach was used in a national survey of soil C in rainforests of Papua New Guinea [40], and in addition, at each site, one sample was taken from the subsoil at $30-60 \mathrm{~cm}$ depth and another at $60-100 \mathrm{~cm}$ depth. McIntosh et al. [41] found that 10 topsoil samples per plot, separately analysed, were sufficient to demonstrate significant $(P<0.05)$ differences between soil $\mathrm{C}$ concentrations under different vegetation types and land uses in loessial soils of southern New Zealand.

For reasons of logistics mentioned above, including the limitations imposed by the necessity for manual sampling by a small team in dense forests, sampling followed procedures developed for quantitative (per hectare) soil C measurement in forests of Papua New Guinea [40], except that samples were individually analysed rather than bulked. For topsoil sampling, an Eijkelkamp split-tube sampler taking a $48 \mathrm{~mm}$ diameter core was used. Ten cores to $30 \mathrm{~cm}$ depth in mineral soil (excluding any litter or O horizon) were sampled within a typical and undisturbed area under each forest type (mixed forest or rainforest). Each core was split into 3 depth increments $(0-10 \mathrm{~cm}, 10-20 \mathrm{~cm}$, and $20-30 \mathrm{~cm})$ and separately bagged for later analysis. A soil pit was dug to $1 \mathrm{~m}$ depth or a rock contact and photographed, described and classified. Subsoils were sampled at $30-60 \mathrm{~cm}$ and $60-100 \mathrm{~cm}$ depths, or to a rock contact (sites 1 and 7). Subsoil bulk density samples were taken with an aluminium tube $(75 \mathrm{~mm}$ internal diameter and length $100 \mathrm{~mm}$ ), at $40-50 \mathrm{~cm}$ and $75-85 \mathrm{~cm}$ depths, where the rock contact allowed.

Samples were air-dried at about $25^{\circ} \mathrm{C}$ and weighed. For each depth increment, subsamples were oven-dried at $105^{\circ} \mathrm{C}$ and passed through a $2 \mathrm{~mm}$ sieve to remove stones and determine the effective bulk density (EBD) of respective $<2 \mathrm{~mm}$ diameter fractions.

2.3. Organic Matter Analysis. Acid soil $\mathrm{pH}$ values and tests with $\mathrm{HCl}$ indicated that no free carbonates were present in any profile. At sites $1-5$, total $\mathrm{C}$ and $\mathrm{N}$ were analysed by combusting finely ground $0.1 \mathrm{~g}$ subsamples in a Vario Macro Cube elemental analyser, and the labile $\mathrm{C}$ fraction was measured using a hot water extraction method as outlined by Ghani et al. [42]. At sites 6 and 7, a similar combustion method was used: analysis was performed with a Euro EA Elemental Analyser (HEKAtech GmbH, Wegberg, Germany).

Physical soil organic matter (SOM) fractionation was undertaken on sieved air-dried soil samples for two 
TABLE 2: Site details.

\begin{tabular}{|c|c|c|c|c|c|c|c|c|}
\hline Site ID & $\begin{array}{l}\text { Parent } \\
\text { material }\end{array}$ & $\begin{array}{l}\text { Mean } \\
\text { annual } \\
\text { rainfall } \\
(\mathrm{mm})\end{array}$ & $\begin{array}{l}\text { Mean max. } \\
\text { and mean min. } \\
\text { temp. }{ }^{4}\left({ }^{\circ} \mathrm{C}\right)\end{array}$ & $\begin{array}{c}\text { FAO soil } \\
\text { classification } \\
\text { (FAO [33]) }\end{array}$ & $\begin{array}{l}\text { Forest } \\
\text { type }\end{array}$ & $\begin{array}{l}\text { Altitude } \\
\text { (m) }\end{array}$ & $\begin{array}{l}\text { Latitude/ } \\
\text { longitude }\end{array}$ & $\begin{array}{l}\text { Moroni } \\
\text { et al. [11] } \\
\text { site }\end{array}$ \\
\hline \multirow{2}{*}{$\begin{array}{l}\text { (1) Mueller } \\
\text { Road }\end{array}$} & \multirow{2}{*}{$\begin{array}{l}\text { Permian } \\
\text { siltstone }\end{array}$} & $1167^{1}$ & $\begin{array}{c}13.7 \\
4.1\end{array}$ & Gleysol & Rainforest & 640 & $\begin{array}{l}42^{\circ} 48.018^{\prime} \mathrm{S} \\
146^{\circ} 31.465^{\prime} \mathrm{E}\end{array}$ & 4 \\
\hline & & $1167^{1}$ & $\begin{array}{c}13.7 \\
4.1 \\
\end{array}$ & Gleysol & Mixed & 640 & $\begin{array}{l}42^{\circ} 47.986^{\prime} \mathrm{S} \\
146^{\circ} 31.474^{\prime} \mathrm{E}\end{array}$ & 3 \\
\hline \multirow{2}{*}{ (2) Styx Road } & \multirow{2}{*}{$\begin{array}{c}\text { Quaternary } \\
\text { colluvium from } \\
\text { siltstone }\end{array}$} & $1167^{1}$ & $\begin{array}{c}14.2 \\
4.4\end{array}$ & Cambisol & Rainforest & 560 & $\begin{array}{l}42^{\circ} 47.768^{\prime} \mathrm{S} \\
146^{\circ} 34.930^{\prime} \mathrm{E}\end{array}$ & 8 \\
\hline & & $1167^{1}$ & $\begin{array}{c}14.1 \\
4.3 \\
\end{array}$ & Cambisol & Mixed & 587 & $\begin{array}{l}42^{\circ} 47.700^{\prime} \mathrm{S} \\
146^{\circ} 34.928^{\prime} \mathrm{E}\end{array}$ & 7 \\
\hline \multirow{2}{*}{ (3) Eleven Road } & \multirow[t]{2}{*}{$\begin{array}{c}\text { Quaternary } \\
\text { colluvium from } \\
\text { sandstone }\end{array}$} & $1167^{1}$ & $\begin{array}{c}14.2 \\
4.4\end{array}$ & Podzol & Rainforest & 564 & $\begin{array}{l}42^{\circ} 43.076^{\prime} \mathrm{S} \\
146^{\circ} 31.073^{\prime} \mathrm{E}\end{array}$ & 12 \\
\hline & & $1167^{1}$ & $\begin{array}{c}14.4 \\
4.5 \\
\end{array}$ & Podzol & Mixed & 533 & $\begin{array}{l}42^{\circ} 36.664^{\prime} \mathrm{S} \\
146^{\circ} 5.362^{\prime} \mathrm{E}\end{array}$ & 11 \\
\hline \multirow{2}{*}{$\begin{array}{l}\text { (4) Florentine } \\
\text { Road }\end{array}$} & \multirow{2}{*}{$\begin{array}{l}\text { Mixed } \\
\text { quaternary } \\
\text { alluvium }\end{array}$} & $1167^{1}$ & $\begin{array}{c}14.9 \\
4.7\end{array}$ & Cambisol & Rainforest & 464 & $\begin{array}{l}42^{\circ} 43.076^{\prime} \mathrm{S} \\
146^{\circ} 1.073^{\prime} \mathrm{E}\end{array}$ & 6 \\
\hline & & $1167^{1}$ & $\begin{array}{c}14.9 \\
4.7 \\
\end{array}$ & Cambisol & Mixed & 463 & $\begin{array}{l}42^{\circ} 43.068^{\prime} \mathrm{S} \\
146^{\circ} 31.123^{\prime} \mathrm{E}\end{array}$ & 5 \\
\hline \multirow{2}{*}{ (5) Sumac Road } & \multirow{2}{*}{$\begin{array}{c}\text { Precambrian } \\
\text { dolerite }\end{array}$} & $1524^{2}$ & $\begin{array}{c}15.8 \\
6.9\end{array}$ & Ferralsol & Rainforest & 226 & $\begin{array}{c}41^{\circ} 7.244^{\prime} \mathrm{S} \\
145^{\circ} 0.566^{\prime} \mathrm{E}\end{array}$ & 24 \\
\hline & & $1524^{2}$ & $\begin{array}{c}15.8 \\
6.9 \\
\end{array}$ & Ferralsol & Mixed & 227 & $\begin{array}{c}41^{\circ} 7.303^{\prime} \mathrm{S} \\
145^{\circ} 0.510^{\prime} \mathrm{E}\end{array}$ & 23 \\
\hline \multirow{2}{*}{$\begin{array}{l}\text { (6) South Esk } \\
\text { Road }\end{array}$} & \multirow{2}{*}{$\begin{array}{l}\text { Devonian } \\
\text { granite }\end{array}$} & $966^{3}$ & $\begin{array}{c}13.1 \\
4.9\end{array}$ & Umbrisol & Rainforest & 793 & $\begin{array}{l}41^{\circ} 23.095^{\prime} \mathrm{S} \\
147^{\circ} 40.227^{\prime} \mathrm{E}\end{array}$ & 21 \\
\hline & & $966^{3}$ & $\begin{array}{c}13.2 \\
5.0\end{array}$ & Umbrisol & Mixed & 779 & $\begin{array}{l}41^{\circ} 23.458^{\prime} \mathrm{S} \\
147^{\circ} 40.464^{\prime} \mathrm{E}\end{array}$ & 20 \\
\hline \multirow{2}{*}{ (7) Tipunah } & \multirow{2}{*}{$\begin{array}{l}\text { Precambrian } \\
\text { siltstone }\end{array}$} & $1524^{2}$ & $\begin{array}{c}16.1 \\
7.1\end{array}$ & Stagnosol & Rainforest & 178 & $\begin{array}{l}40^{\circ} 57.806^{\prime} \mathrm{S} \\
145^{\circ} 16.521^{\prime} \mathrm{E}\end{array}$ & $\begin{array}{c}\text { Not } \\
\text { applicable }\end{array}$ \\
\hline & & $1524^{2}$ & $\begin{array}{c}16.1 \\
7.0 \\
\end{array}$ & Stagnosol & Mixed & 184 & $\begin{array}{l}40^{\circ} 57.761^{\prime} \mathrm{S} \\
145^{\circ} 16.532^{\prime} \mathrm{E}\end{array}$ & $\begin{array}{c}\text { Not } \\
\text { applicable }\end{array}$ \\
\hline
\end{tabular}

${ }^{1}$ Mean annual rainfall for Maydena weather station 95063 at $281 \mathrm{~m}$ altitude [31]. Rainfall at the site is likely to be higher. ${ }^{2}$ Mean annual rainfall at Luncheon Hill weather station 91259 at $345 \mathrm{~m}$ altitude [31]. Rainfall at the site is likely to be lower. ${ }^{3}$ Mean annual rainfall at Scottsdale weather station 91219 at $198 \mathrm{~m}$ altitude [31]. Rainfall at the site is likely to be higher. ${ }^{4}$ Derived from mean temperatures for Maydena (for sites 1-4), Smithton (sites 5-7), and Scottsdale (site 6) [31], to which the lapse rates of Nunez [32] have been applied.

contrasting sites: Sumac Road and Eleven Road (Table 2). A composite sample $(30 \mathrm{~g})$ derived from the right, middle, and left soil profile wall was prepared for the uppermost (B1 or A1) and lowermost (C or Bhs) horizons at these two sites, respectively, to identify differences between forest types as well as between topsoils and subsoils (the Bhs horizon at Eleven Road is a B horizon rich in humus and sesquioxides). The fractionation procedure combined density and particlesize fractionation (Kögel-Knabner [43]). The bulk sample was homogenised in a glass beaker and sprayed with water to reduce hydrophobicity and remove entrapped air. $150 \mathrm{ml}$ of sodium polytungstate (SPT) solution $\left(1.8 \mathrm{~g} \cdot \mathrm{cm}^{-3}\right)$ was added gradually to saturate the sample and finally submerge it. The suspension was left standing overnight to allow separation of lighter and heavier fractions. Free-floating particles, representing free particulate organic matter (fPOM), were removed with a vacuum pump and washed using pressure filtration and $0.22 \mu \mathrm{m}$ membrane filters (Berrytec $\mathrm{GmbH}$ ) until the outflow had an electrical conductivity (EC) of $<2 \mu \mathrm{S}$ $\mathrm{cm}^{-1}$. Subsequently, the fPOM was freeze-dried. The heavier fraction was subjected to ultrasonication (Sonoplus HD
2200 , Bandelin, Berlin, Germany) applying $600 \mathrm{~J} \cdot \mathrm{ml}^{-1}$ at $70 \%$ intensity to break up soil aggregates and release occluded particulate organic matter (oPOM). To avoid strong heating and consequent mutation of released fragments, the suspension was cooled with water during this step. Samples were centrifuged $(3500 \mathrm{rpm}, 30 \mathrm{~min})$, and the free-floating oPOM was removed by suction. The extracted oPOM was partitioned into $>20 \mu \mathrm{m} \quad($ oPOM $>20)$ and $<20 \mu \mathrm{m}$ $(\mathrm{oPOM}<20)$ fractions by sieving. Both fractions were washed until outflows had an EC of $2 \mu \mathrm{S} \mathrm{cm}^{-1}$, and then freeze-dried. The mineral residue was repeatedly purged with deionized water and centrifuged (3500-5000 rpm, $30 \mathrm{~min}$ ) until the EC of the supernatant was below $50 \mu \mathrm{S}$ $\mathrm{cm}^{-1}$. The residue was wet sieved to obtain coarse sand $(2000-630 \mu \mathrm{m})$, medium sand $(630-200 \mu \mathrm{m})$, fine sand $(200-63 \mu \mathrm{m})$, and coarse silt $(63-20 \mu \mathrm{m})$ fractions. The outflow was collected to further separate medium silt $(20-6.3 \mu \mathrm{m})$ from fine silt and clay $(<6.3 \mu \mathrm{m})$ by gravity sedimentation in Atterberg-type cylinders, making use of Stokes' law. The two size fractions were freeze-dried, and all remaining mineral fractions were dried at $65^{\circ} \mathrm{C}$. Thereupon, 
mineral fractions $>20 \mu \mathrm{m}$ were ground with a swing mill ( $3 \mathrm{~min}$ ). The $\mathrm{PPOM}$ and $\mathrm{oPOM}>20$ fractions were ground by hand using a mortar. Processed samples were put in glass vials and stored at room temperature until elemental analysis.

The chemical composition of $\mathrm{fPOM}$, oPOM $>20$, $\mathrm{oPOM}<20$, and clay fractions was analysed using $13 \mathrm{C}$ CPMAS NMR spectroscopy. A Bruker Advance III 200 Spectrometer was used, coupled with a Bruker MAS II control unit, and operated with Bruker BioSpin software. The NMR rotor was spun at a MAS spin rate of $6.8 \mathrm{kHz}$ with varying recycle delay time and scan counts. (The recycle delay time refers to the time between individual scans, while scan counts refer to the total number of scans required until an appropriate spectrum could be identified.) Fractions with a relatively high $\mathrm{C}$ concentration, i.e., mainly fPOM, $\mathrm{oPOM}>20$, and $\mathrm{OPOM}<20$, for which sufficient material was available from the fractionation procedure, were scanned with a recycle delay time of $1.0 \mathrm{~s}$ while scan counts ranged between 3,400 and 91,400. For fractions showing a low C concentration, i.e., mainly clay fractions, or fractions containing only small amounts of material from the fractionation procedure, the recycle delay time was set to $0.4 \mathrm{~s}$ and up to 370,000 scans were required to obtain quality spectra. The clay fraction of the samples of the Ferralsol at Sumac Road required most scan counts: this fraction combined low $\mathrm{C}$ contents with high contents of pedogenic Fe. Pedogenic Fe has the potential to reduce the ${ }^{13} \mathrm{C}$ signal and thus lead to less distinct peaks [44], which increases the number of scans required. After the samples were scanned, the spectra were processed with line broadening ranging from 0 to $75 \mathrm{~Hz}$, depending on the distinctness of their peaks. Furthermore, the spectra were phase adjusted and baseline corrected (in an automatic mode). The interpretation of spectra followed principles outlined in detail by Kögel-Knabner et al. [45].

2.4. Statistical Analysis. Standard deviations were calculated for all means (Table 3 ). The effect of forest type on bulk soil $\mathrm{C} / \mathrm{N}$ ratios in both top- and subsoil was tested based on estimation graphs as demonstrated by Gardner and Altmann [46]. The graphs show the $95 \%$ confidence interval, which is determined via bootstrap resamples (5000 repetitions) of the effect size. Bootstrap was bias-corrected to account for skew. This was accomplished using the Python (version 3.7) module DABEST [47].

\section{Results}

3.1. Carbon Content of Site Pairs and C/N Ratios. The soils under rainforest and mixed forest contain 110 to $326 \mathrm{Mg} \cdot \mathrm{ha}^{-1}$ (Table 3; Figure 3) of total C. No statistical difference between soil $\mathrm{C}$ values under rainforest and mixed forest ( $t$-test, $P>0.05)$ was detected: mean values were $203 \mathrm{Mg} \cdot \mathrm{ha}^{-1}$ in soils under rainforest and $199 \mathrm{Mg} \cdot \mathrm{ha}^{-1}$ in soils under mixed forest. The latter figure is close to the mean value measured by Cotching ([50], p. 86) to $1 \mathrm{~m}$ depth for six soil orders under unspecified native forest in Tasmania (193 Mg.ha ${ }^{-1}$; range $94-273 \mathrm{Mg} \cdot \mathrm{ha}^{-1}$ ) but higher than the mean soil figure obtained for wet eucalypt forests in earlier surveys (147 Mg.ha ${ }^{-1}$; Table 1) probably because the earlier surveys were not confined to mixed forest containing mature eucalypts and included very stony profiles (the stoniest profile contained c. $70 \%$ stones by volume and $37 \mathrm{Mg} \cdot \mathrm{ha}^{-1}$ of C). Such profiles were not sampled in this study.

In deep soils sampled to $100 \mathrm{~cm}$ depth (Table 3, sites 2-6), 39-76\% (mean 50\%) of the soil C is held below $30 \mathrm{~cm}$ depth (Table 3; Figure 4). The clay-rich Styx Road Cambisols developed in Quaternary colluvium contained most C (300-326 Mg.ha $\left.{ }^{-1}\right)$.

There was no significant difference between $\mathrm{C} / \mathrm{N}$ ratios in uppermost (A1 and B1) horizons sampled under rainforest and mixed forest; mean values were 20-22 (Figure 5). However, in lowermost horizons sampled (generally, B3, C, $\mathrm{BCg}$, or $\mathrm{Bh}$ horizons), $\mathrm{C} / \mathrm{N}$ ratios were significantly higher in soils under mixed forests $(17 \pm 5)$ than under rainforests $(13 \pm 6)$ (Figure 5).

During sample preparation, $50 \%$ of the samples $(n=102)$ taken from mixed forest profiles were observed to contain identifiable pieces of pyrogenic $\mathrm{C}$ (charcoal) in the $>2 \mathrm{~mm}$ fraction, but only $16 \%$ of the samples $(n=92)$ taken from rainforest profiles contained identifiable pyrogenic $\mathrm{C}$.

Mean total $\mathrm{C}$ pools in mixed forests and rainforests were estimated (Table 4) using the soil data of this paper and the biomass data of Moroni et al. [11] and Moroni et al. [10], who assumed that roots contain $25 \%$ of measured aboveground biomass [51, 52].

3.2. Soil Organic Matter Characterisation. The distribution of $\mathrm{C}$ among SOM fractions varied between sites and with soil depth. In the uppermost (B1) horizons at Sumac Road, most $\mathrm{C}$ was found in the clay fraction, with slightly more under mixed forest (68\%) than rainforest (60\%) (in Ferralsol profiles under both rainforest and mixed forest, an A1 horizon as defined by the National Committee on Soil and Terrain [53] was not present and the B1 horizon was the uppermost mineral horizon). The remaining $\mathrm{C}$ was largely in the oPOM form with a negligible contribution of $\mathrm{PPOM}$. In contrast at Sumac Road under rainforest, $75 \%$ of total C in the $\mathrm{C}$ horizon was held in the oPOM $<20$ fraction compared to $6 \%$ in this fraction below mixed forest. This subsoil difference may reflect different SOM stabilisation mechanisms in subsoils under the two forest types, as observed in forests elsewhere [54] and in agricultural systems [55]. In the uppermost (A1) horizon at Eleven Road under mixed forest, most $C$ was held in the oPOM $<20$ fraction, but under rainforest, most was held in the clay fraction. The Bhs horizons under both forest types had highest $\mathrm{C}$ contents in the clay fraction.

In the Ferralsols at Sumac Road (site 5), the fPOM extracted from the $<2 \mathrm{~mm}$ B1 horizon under mixed forest had a distinct NMR peak in the aromatic aryl-C region $(130 \mathrm{ppm})$, indicating the presence of pyrogenic $C[56,57]$ in this horizon under mixed forest; this peak was not detected in the B1 horizon under rainforest (Figure 6). In the fPOM fraction of the $\mathrm{B} 1$ horizon under mixed forest $28 \%$ of the total contribution was derived from aryl-C, whereas under 


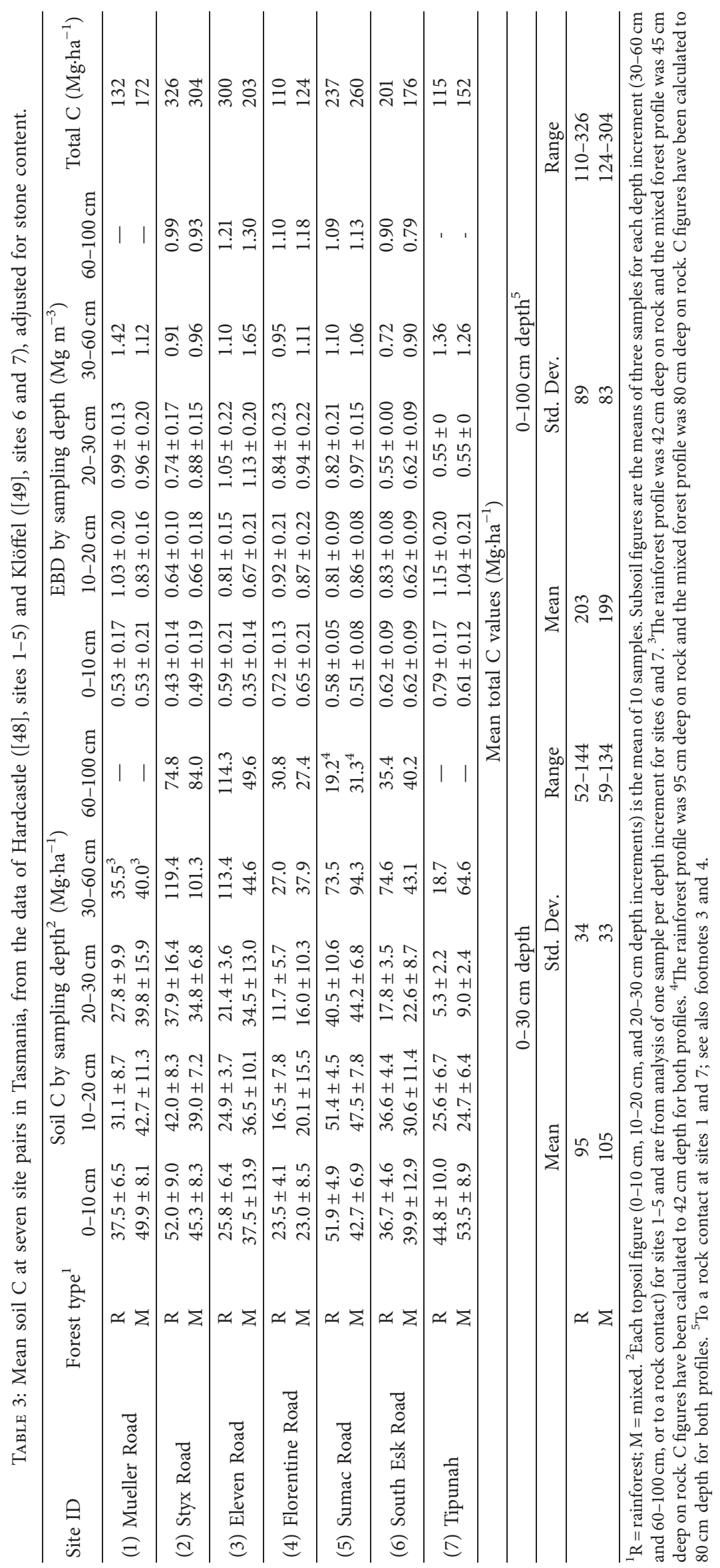




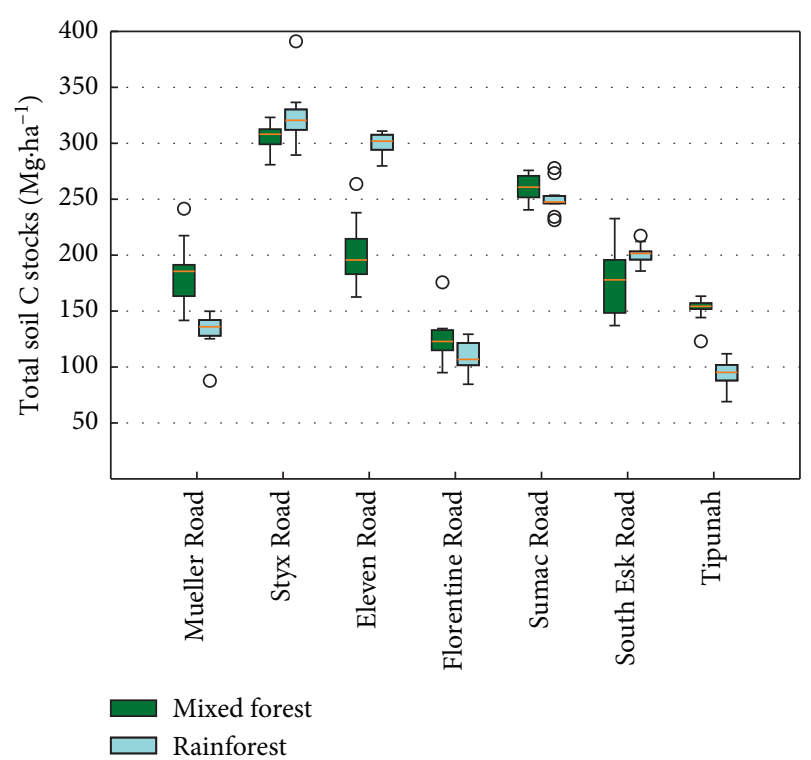

Figure 3: Total C held in soils to $1 \mathrm{~m}$ depth or to a rock contact at shallower depth (Mueller Road and Tipunah sites). Green shading = mixed forest; blue shading $=$ rainforest. The bars indicate $1.5 \mathrm{x}$ the interquartile range. Open circles indicate values outside this range.

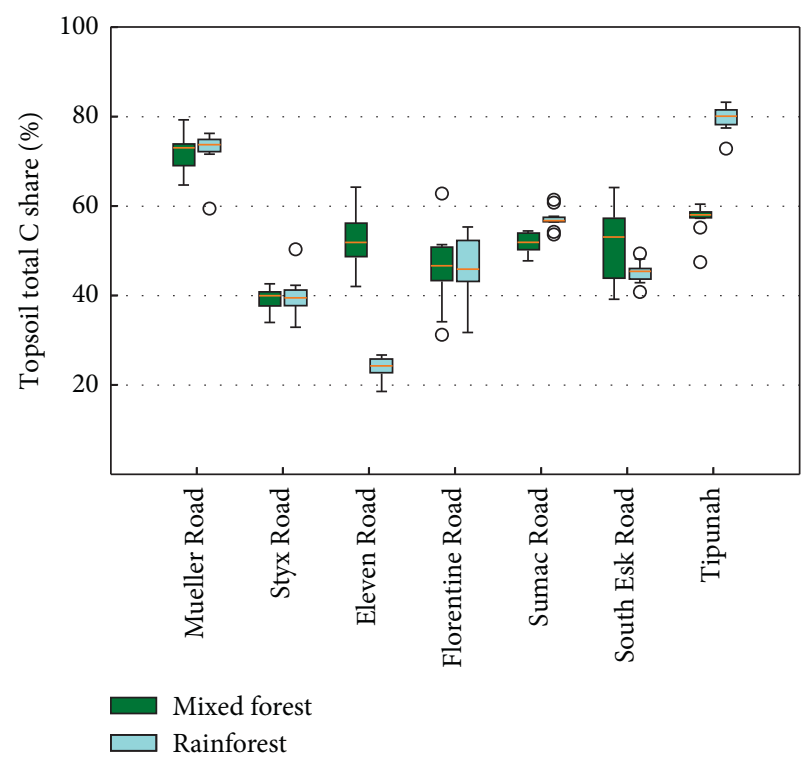

Figure 4: Proportion of total C held in topsoils $(0-30 \mathrm{~cm}$ depth). Green shading = mixed forest; blue shading $=$ rainforest. The bars indicate $1.5 \mathrm{x}$ the interquartile range. Open circles indicate values outside this range.

rainforest, the respective aryl-C contribution was only $15 \%$. In Ferralsol subsoils (Figure 7), no clear differences of aryl-C under rainforest and mixed forest were apparent.

Eluviation of pyrogenic $\mathrm{C}$ through profiles is confirmed by the weak aryl-C peak in NMR analyses of organic/clay coatings in the Bhs horizon of the rainforest Podzol at Eleven Road (Figure 7) which contains 3.4\% C. Unfortunately the amount of $\mathrm{PPOM}$ and oPOM material in Podzol subsoil samples was insufficient for all organic fractions to be analysed, and usable spectra for samples under mixed forest were not obtained. The $\mathrm{NaOH}$-insoluble fraction of the organic matter in the rainforest Bhs horizon (Figure 7(a)) was radiocarbon dated by accelerator mass spectrometry (AMS) to $2882 \pm 24 \mathrm{yr}$ BP (Wk49496, uncalibrated). In another study (P. McIntosh, unpublished data), organic matter from a podzol pan in northeast Tasmania was dated $3133 \pm 38 \mathrm{BP}$ (Wk17421, uncalibrated), after similar $\mathrm{NaOH}$ pretreatment. If it is assumed that $\mathrm{C}$ illuviation is a continuous process under the present climate, then these dates are the average age of $\mathrm{C}$ illuviation in these soils, and the subsoil horizons analysed may well be around 6000 years old or older. However, some profiles are younger: buried charcoal at $1 \mathrm{~m}$ depth in the Umbrisol under mixed forest in granitic colluvium under mixed forest at site 6 (South Esk Road) (Table 1 and Figure 2) was dated $1838 \pm 14 \mathrm{yr}$ BP (Wk49497, uncalibrated), and probably dates localised erosion, for example, fall of a large eucalypt tree with its intact root-ball of soil, following a fire.

\section{Discussion}

4.1. Soil Carbon Stocks. There is no evidence that soil C either increases or decreases during the transition of mixed forests to rainforests (Table 3). Soil C stocks are within the range of previous profile values (Table 1; [50]). It is most unlikely that, even if significant soil $\mathrm{C}$ differences were detected by more detailed and statistically robust studies, they would be sufficiently large to balance the loss of total biomass $\mathrm{C}$ (mean value $259 \mathrm{Mg} \cdot \mathrm{ha}^{-1}$; Table 4 ) resulting from the transition of mixed forests to rainforests. In addition, as rainforest sites had little litter cover and litter in mixed forests was mainly in the form of bark accumulations at the base of large eucalypts, taking account of litter (estimated by Mackey et al. ([15], p. 22 ) to be $2 \%$ of total biomass and soil $\mathrm{C}$ in mature eucalypt forest) would probably accentuate the biomass $C$ difference between rainforest and mixed forest, rather than lessen it.

The mean amount of soil $\mathrm{C}$ held below $30 \mathrm{~cm}$ depth for all profiles is $50 \%$, demonstrating the importance of sampling full profiles to $1 \mathrm{~m}$ depth or a rock contact when calculating ecosystem $\mathrm{C}$ storage. The mean $\mathrm{C}$ contained at $0-30 \mathrm{~cm}$ depth under mixed eucalypt forests in this study (Table 3) is $95 \mathrm{Mg} \cdot \mathrm{ha}^{-1}$ (range $52-144 \mathrm{Mg} \cdot \mathrm{ha}^{-1}$ ); previously published estimates of forest soil $\mathrm{C}$ under mixed forests and rainforest are too high and not based on information available at the time of publication. For example, the unreferenced $271 \mathrm{Mg} \cdot \mathrm{ha}^{-1}$ value quoted in 2010 by Dean and Wardell-Johnson [27] for soil C at 0-30 cm depth under tall old-growth forest in Tasmania is almost three times the figure measured in this study and over twice the highest measured forest $C$ value at $0-30 \mathrm{~cm}$ soil depth in Tasmania

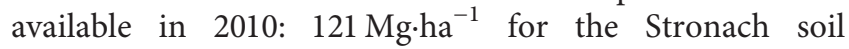
(Umbrisol) formed in granite colluvium in northeast Tasmania [21]. Likewise, the unreferenced $369 \mathrm{Mg} \cdot \mathrm{ha}^{-1}$ of $\mathrm{C}$ at $0-30 \mathrm{~cm}$ depth quoted by Dean and Wardell-Johnson ([27], Table 1) for rainforest soils in Tasmania is over three times too high: in 2010, the mean measured $C$ value for $0-30 \mathrm{~cm}$ soils at three rainforests sites in Tasmania (Table 1) was $102 \mathrm{Mg} \cdot \mathrm{ha}^{-1}$, almost identical to the mean value of $105 \mathrm{Mg} \cdot \mathrm{ha}^{-1}$ measured in this study (Table 3). In addition, 


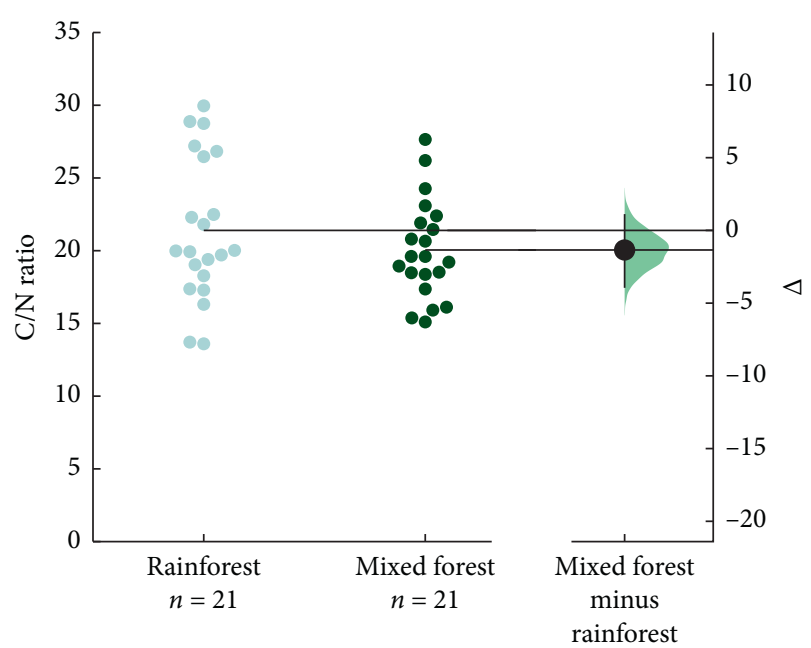

(a)

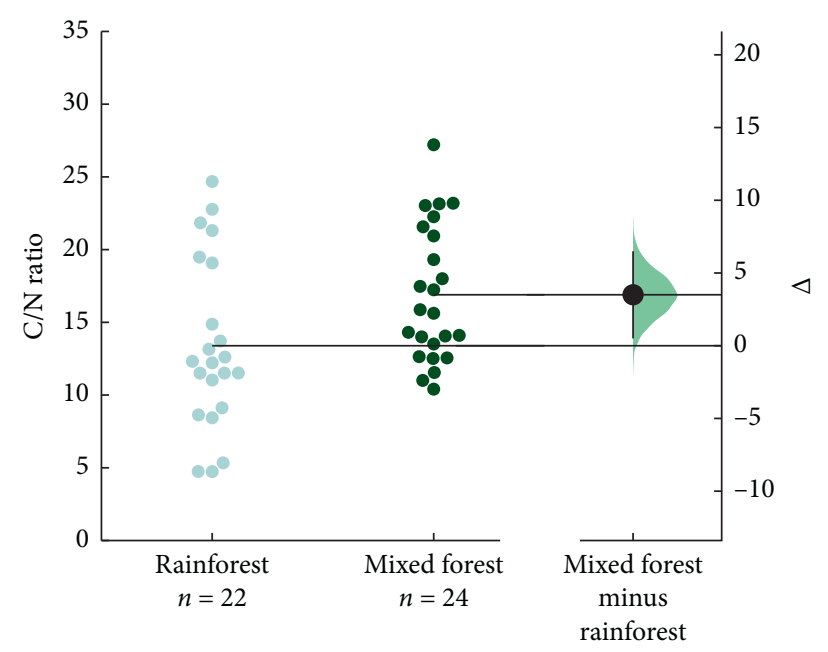

(b)

FIGURE 5: Estimation graphs [45] comparing $\mathrm{C} / \mathrm{N}$ ratios of soils under rainforest and mixed forests for (a) uppermost (A1 or B1) horizons and (b) lowermost (B3, C, BCg, or Bhs) horizons. The $95 \%$ confidence interval, indicated by vertical black bars, is obtained via bootstrap resampling (5000 repetitions). The horizontal black lines represent mean $\mathrm{C} / \mathrm{N}$ ratios for each forest type. The vertical curve indicates the resampled distribution.

TABLE 4: Estimated mean C pools in mixed forests and rainforests of Tasmania and C in each pool expressed as a percentage of total C in the ecosystem. Standard deviations in parentheses.

\begin{tabular}{|c|c|c|c|c|c|}
\hline \multirow{2}{*}{ Forest type } & \multicolumn{5}{|c|}{ Carbon $\left(\mathrm{Mg} \cdot \mathrm{ha}^{-1}\right)$} \\
\hline & Soil $^{1}$ & Aboveground biomass ${ }^{2}$ & Roots & Total biomass & Total biomass and soil \\
\hline \multirow{2}{*}{ Rainforest } & $203(89)$ & $171(75)$ & $43^{3}$ & 214 & 417 \\
\hline & $48 \%$ & $41 \%$ & $11 \%$ & $52 \%$ & \\
\hline \multirow{2}{*}{ Mixed forest } & $199(83)$ & $378(173)$ & $95^{4}$ & 473 & 672 \\
\hline & $30 \%$ & $56 \%$ & $14 \%$ & $70 \%$ & \\
\hline
\end{tabular}

${ }^{1}$ This study. ${ }^{2}$ From Moroni et al. [11], Table $2 .{ }^{3}$ There are no studies of root mass in Australian temperate rainforests so the default value based on $25 \%$ of aboveground biomass [51] has been used. ${ }^{4}$ The default figure, based on $25 \%$ of aboveground biomass [51, 52]. The actual mean $(n=6)$ for tall eucalypt forest $>30 \mathrm{~m}$ high is $90 \mathrm{Mg} \mathrm{ha}^{-1}\left(\mathrm{SE}=19{\left.\mathrm{Mg} \cdot h \mathrm{~h}^{-1}\right)}^{-}([51], \mathrm{p} .62)\right.$, but as the eucalypts in the mixed forests in this study were mature and close to their maximum height, the larger figure is more likely to be correct.

Dean and Wardell-Johnson [27] provided no evidence to support their assertion that $C$ levels in soils at $0-30 \mathrm{~cm}$ depth soils under rainforest exceed those under old-growth (euca-

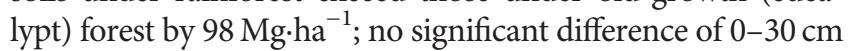
soil C between these two forest types was found in this study (Table 3) or in the study conducted by Fedrigo et al. [30].

The unreferenced c. $700 \mathrm{Mg} \cdot \mathrm{ha}^{-1}$ "baseline" soil C figure for the "full soil profile" of undefined depth under Tasmanian E. regnans forest used by Dean and Wardell-Johnson ([27], Figure 8) is more than twice the maximum measured soil $C$ value under E. regnans available to these authors in 2010 which was $273 \mathrm{Mg} \cdot \mathrm{ha}^{-1}$ in the previously mentioned Stronach profile [21]. The $700 \cdot \mathrm{Mg} \cdot \mathrm{ha}^{-1}$ value also exceeds the highest published forest soil $\mathrm{C}$ figure known to the authors for a forested nonswamp site in the Australasian region $\left(600 \mathrm{Mg} \cdot \mathrm{ha}^{-1}\right)$ measured in a Papua New Guinea soil formed in gabbroic alluvium [58] and is more than three times the mean mixed forest soil C figure in this study (Table 3).

There are numerous references to total soil $\mathrm{C}$ in Tasmanian forests by May et al. [28] but the soil depth to which their figures refer is not specified, although one estimate
([28], p. 17) refers to " $<30 \mathrm{~cm}$ " soils and another refers to "A and B horizons" (p. 274). Whether their average soil C

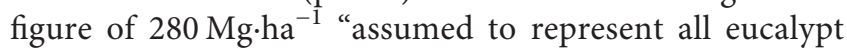
forests in southeast Australia" ([28], p. 274) refers to $0-30 \mathrm{~cm}$ or $0-1 \mathrm{~m}$ depth, it is at least two times too high for Tasmanian eucalypt forests, in which the mean soil $\mathrm{C}$ in information available to May and co-authors in 2012 for all eucalypt forests in Tasmania was $123 \mathrm{Mg} \cdot \mathrm{ha}^{-1}$ for $0-1 \mathrm{~m}$

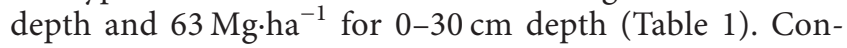
sequently modelled potential $\mathrm{C}$ sequestration figures published by May et al. ([28], p. 54, Figure 4 and Table 5), unfortunately promoted with the aim to "develop a clear accounting framework for carbon stocks and flows in Tasmania's forests" ([28], p. 10), are overestimated and incorrect. Similarly, the modelled losses in soil C from "oldgrowth" (mixed) eucalypt forests after land-use change (e.g., the $300 \mathrm{Mg} \cdot \mathrm{ha}^{-1}$. C loss modelled by Dean and Wardell-Johnson [27]) based on the unreferenced $700 \mathrm{Mg} \cdot \mathrm{ha}^{-1}$ baseline is, in turn, overestimated; the estimated loss exceeds the total $\mathrm{C}$ held in most forest soils as determined in this and previous studies (Table 1). 


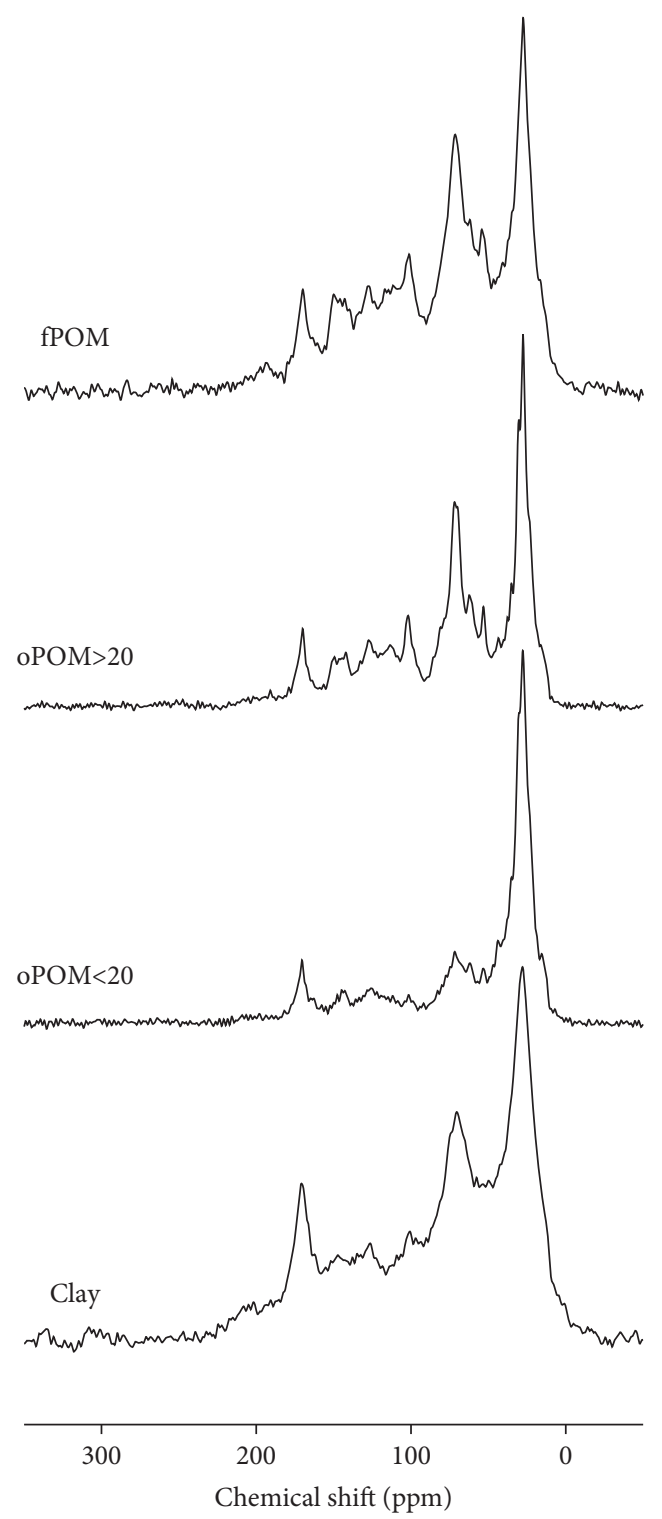

(a)

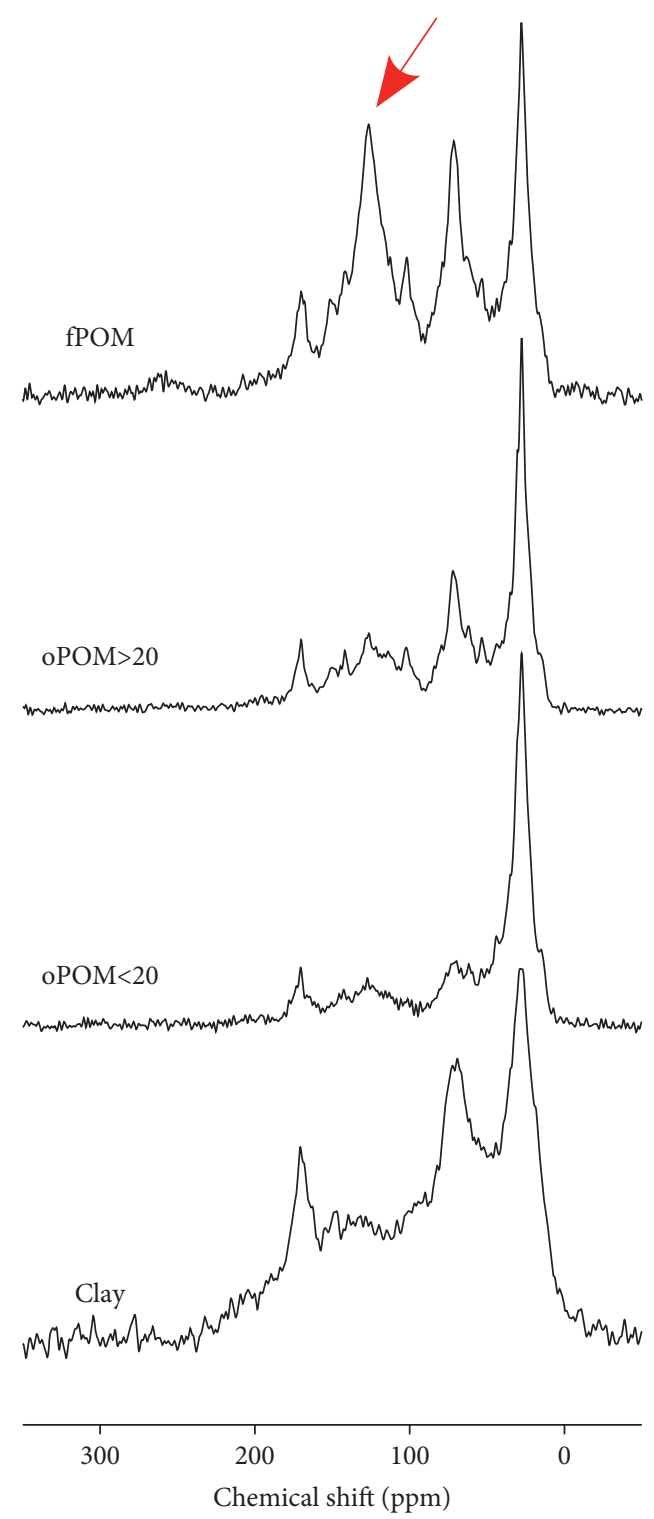

(b)

FIGURE 6: Site 5 Ferralsols: NMR spectra of fPOM, oPOM, and clay fractions from the B1 horizons (uppermost mineral soil horizons) under rainforest (a) and mixed forest (b). The prominent aryl-C peak in the fPOM fraction under mixed forest is arrowed.

In their baseline map of soil $\mathrm{C}$ at $0-30 \mathrm{~cm}$ depth, designed to support national carbon accounting in Australia, Viscarra Rossell et al. [39] estimated that the largely forested lands of western Tasmania contained $161-220 \mathrm{Mg}^{-\mathrm{ha}^{-1}}$ of C in soils at $0-30 \mathrm{~cm}$ depth. When compared to the range of $\mathrm{C}$ values found in this study for soils with few or no stones (52-144 Mg.ha ${ }^{-1}$; Table 3), the modelled range appears to be an overestimate, especially as large areas of forested western Tasmania are steeplands with stony soils. Consequently, the mean C figure for all Tasmanian soils at $0-30 \mathrm{~cm}$ depth $\left(134 \mathrm{Mg} \cdot \mathrm{ha}^{-1}\right.$, [39]) may also have been overestimated.

The similarity of mean measured soil C stocks under mixed forest and rainforest, when contrasted with the large difference in the biomass $\mathrm{C}$ of the two forest types (Table 4) and likely greater biomass and $\mathrm{C}$ inputs to the soil under mixed forest than under rainforest, raises three questions: (1)
Is the similarity of mean soil $\mathrm{C}$ values under mixed forest and rainforest a result of soils under rainforest not yet having attained equilibrium with their "new" lower-biomass forest cover? (2) Has soil C under mixed forest been enhanced (above levels expected in forests subject to frequent fire) by an intermittent supply of relatively inert charcoal? (3) Does the soil C measured in these studies represent the balance of $\mathrm{C}$ input and breakdown over millennia rather than centuries and is what we measure now the result of inherited soil C accumulation independent of present vegetation cover?

Although NMR results for a greater range of sites would be advantageous for determining organic matter processes in these soils, the NMR results obtained, together with the observation that charcoal is present in both eucalypt and rainforest soils, and the radiocarbon ages on buried charcoal, allow tentative answers to be provided for the 3 questions 


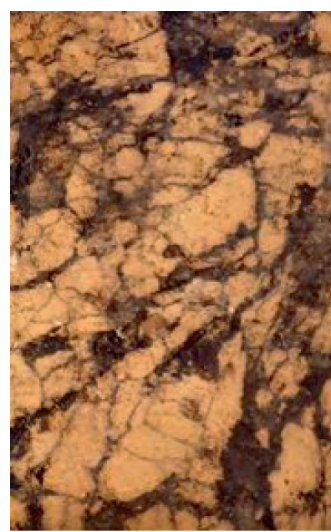

(a)

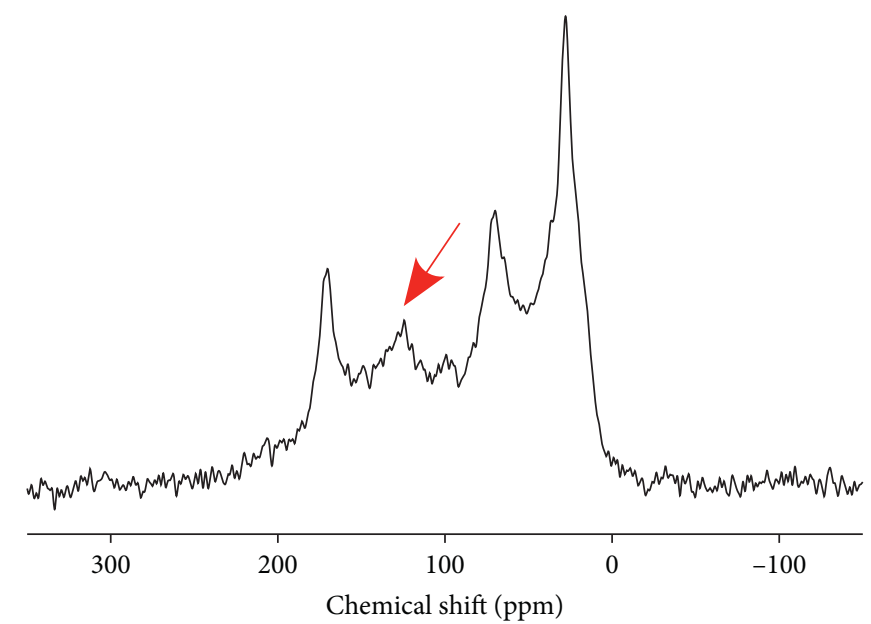

(b)

FIgURE 7: (a) Organic matter/clay coatings on blocky peds in the subsoil (the Bhs horizon) of the Podzol in sandy colluvium under rainforest at Eleven Road. Vertical section, $10 \mathrm{~cm}$ from top to bottom. (b) NMR spectrum for the organic matter/clay coatings; from right to left, the four peaks represent alkyl-C (0-50 ppm), O-alkyl-C (50-110 ppm), aryl-C (110-145 ppm; arrowed), and O-aryl-C (145-160 ppm).

posed above. All three propositions appear to be correct: (1) rainforest soils have not yet attained equilibrium with their "new" lower-biomass forest cover; they still contain a chemical signature of past fires; (2) NMR results show that soil $\mathrm{C}$ levels under mixed forest (and to a lesser extent under rainforest) have been enhanced by intermittent supply of relatively inert (pyrogenic) carbon, as well as other stable carbon fractions; and (3) measured soil C under rainforest retains characteristics of mixed forest cover, and both the amount and character of the $\mathrm{C}$ in the soil under these vegetation types is probably largely inherited and has been determined by processes acting over thousands of years.

However, soil organic matter characteristics are also influenced by present-day vegetation. The greater relative amounts of pyrogenic C (and aryl-C) in Ferralsol surface B1 horizons under mixed forest and the higher mean $\mathrm{C} / \mathrm{N}$ ratio of subsoils under mixed forest than under rainforest is likely to be a consequence of greater fire frequency in the eucalyptdominated mixed forests than in the adjacent rainforests. These effects are discussed below.

4.2. Changes of Soil $C$ after Fire. Measures of short-term change of soil $\mathrm{C}$ stocks after fires have yielded ambiguous results. In a global meta-analysis, Johnson and Curtis [59] noted an increase of soil $\mathrm{C}$ after wildfire (attributed to the sequestration of pyrogenic $\mathrm{C}$ and contributions from postfire nitrogen-fixing plants) but a decrease after prescribed fuel-reduction burns. Pennington et al. [60] noted significant declines of topsoil C concentration at $0-5 \mathrm{~cm}$ and $5-10 \mathrm{~cm}$ depth (from 8.04 to $5.40 \%$ and from 4.12 to $3.41 \%$, respectively) after harvest and a regeneration burn in tall wet eucalypt forests at a southern Tasmania site. However, the difference between unburnt and burnt topsoils at $0-30 \mathrm{~cm}$ depth $\left(5 \mathrm{Mg} \cdot \mathrm{ha}^{-1}\right)$ was not statistically significant once bulk density had been taken into account. No correction was made for stones, but stone content "was shown to be very low" [60]. In contrast, Slijepcevic [61] noted an average $3.5 \%$ increase of topsoil C (from 145 to $150 \mathrm{Mg} \cdot \mathrm{ha}^{-1}$ at $0-10 \mathrm{~cm}$ depth) after harvest and burning in three wet eucalypt coupes (harvest areas). The results were not statistically analysed, but Slijepcevic ([61], p. 285) considered that they "did not provide any evidence of carbon loss or gain from the upper layers after burning." Ellis and Graley [62] found that immediately after "hot" (intense) regeneration burns following eucalypt harvest at two locations in Tasmania, $\mathrm{C}$ in topsoil

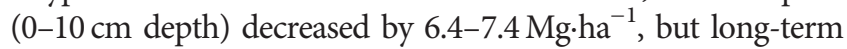
trends were not investigated. In Victoria, Australia, Polglase et al. [63] found that in E. regnans forests regenerating after fire, soil C reached $86 \%$ of equilibrium (steady state) values when the forest was aged 30 years, with "true equilibrium" not being reached until about 150 years. The effect of regular fires on soil properties in wet eucalypt forests was addressed by Guinto et al. [64] who measured a significant $1.9 \%$ decline in $\mathrm{C}$ in soils at $0-10 \mathrm{~cm}$ depth in wet sclerophyll forest soils burnt every two years for 20 years in southeast Queensland. Assuming a topsoil EBD of $0.5 \mathrm{Mg} \cdot \mathrm{ha}^{-1}$ for these $0-10 \mathrm{~cm}$ soils, this 20 -year decline equates to a $\mathrm{C}$ loss of $9 \mathrm{Mg} \cdot \mathrm{ha}^{-1}$. In contrast, Krishnaraj [19] found that topsoil $\mathrm{C}$ under eucalypt forests of the Otway Ranges of southern Victoria increased by $2 \%$ after a forest fire due to accumulation of charcoal.

The different results obtained by these authors probably reflect the problem of adequately covering postdisturbance soil variation by the sampling strategies used. Until more comprehensive work is done, results of these case studies should not be used to generalise about the short-term effect of harvest and burning on soil C. The eucalypt forests investigated in this study must have experienced standdestroying fires more recently than the rainforests, but the effects of fires is not evident in mean total $\mathrm{C}$ values.

4.3. Sequestration of Carbon by Wet Eucalypt Forest. Many authors (e.g., Keith et al. [6], Mackey et al. [15], Dean and Wardell-Johnson [27], May et al. [28], and Dean et al. 
[65]) have promoted the protection of eucalypt forests to mitigate the effects of climate change. The weaknesses in the arguments presented by these authors have been highlighted by Moroni et al. [67] and McIntosh and Moroni [29] who pointed out that (1) mature eucalypt forests are not the steady-state end point of forest succession and (2) that a concept originally designed to assess $\mathrm{C}$ sequestration potential in ecosystems (Gupta and Rao [68]) cannot be applied to landscapes as a management tool. The relevance of this study to these two issues is discussed below.

4.3.1. Forest Succession. The soil studies summarised in Table 3 and Figures 3 and 4 indicate that during the succession from mixed forest to rainforest, no change in mean soil C stocks is detectable. Given the long-term stability of the soils as indicated by NMR analyses and the lower biomass (and probably lower biomass inputs into the soil) under rainforest, and previous measurements of total $\mathrm{C}$ in Tasmanian profiles (Table 1), it appears unlikely that more detailed and statistically robust studies would demonstrate that the loss of biomass $\mathrm{C}\left(259 \mathrm{Mg} \cdot \mathrm{ha}^{-1}\right)$ during the mixed forest/rainforest transition is compensated by an increase in soil C. (The mean value of soil $\mathrm{C}$ measured under rainforests in this study would need to be 2.5 times higher to compensate for the biomass $\mathrm{C}$ loss.) Consequently, it can be concluded that the $\mathrm{C}$ loss resulting from the mixed forest/

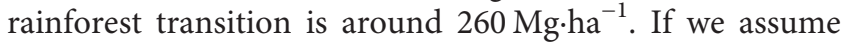
that wet eucalypt forests are tallest (and contain most C) when they are 400-500 years old, that all eucalypt trees have fallen after another 150 years, and that fallen trees have rotted away after another 250 years, then we can calculate that during the mixed forest/rainforest transition, $260 \mathrm{Mg} \cdot \mathrm{ha}^{-1}$ of $\mathrm{C}$ will be released to the atmosphere over an approximately 400 -year period, i.e., $\mathrm{C}$ is lost at a rate of about $0.65 \mathrm{Mg} \cdot \mathrm{ha}^{-1}$ year $^{-1}$. Thus, during natural succession, mature wet eucalypt forests are significant $\mathrm{C}$ emitters, not $\mathrm{C}$ accumulators.

4.3.2. Forest Management. Despite acknowledging that "the role of fire in natural forests is complex and must be considered on a landscape-wide basis" (Mackey et al. [15], p. 20), these authors underestimated the effect of fires on $\mathrm{C}$ accumulation at the landscape scale, even though eucalypt ecosystems are fire-induced. For example, Mackey et al. [15] (p. 23 and 26) excluded bushfire-affected areas when calculating gross primary production, and living biomass $\mathrm{C}$ was calculated only for "undisturbed" forests. The limitation of fires on $\mathrm{C}$ accumulation is evident in areas of Tasmania and the southeast Australian mainland affected by the 2019 and 2020 bushfires (discussed below): while not all burnt eucalypts are killed by fire, the overall effect of crown fires is to halt landscape-scale $\mathrm{C}$ accumulation or reverse it. Because eucalypt forests in their natural state will either burn and regenerate or transition to rainforest in the absence of fire, it is not correct to assume that mature eucalypt forests are a "baseline" against which to judge land-use change, as done, for example, by May et al. ([28], p. 274). Neither the biomass present before disturbance (whether the result of burning, harvesting, or storm damage) nor that present after disturbance represents the potential biomass in the landscape as a whole, and the true biomass potential at a landscape scale will always lie between the disturbed and undisturbed extremes. The biomass $\mathrm{C}$ in the landscape is always in a state of flux and cannot be defined.

Even the concepts of "undisturbed" (Mackey et al. [15]) and "natural" (Keith et al. [66]) must be used cautiously, since Aboriginal management has profoundly affected forest structure in Tasmania for many thousands of years. Early European settlers remarked on fire use by the Aboriginal population [69-72]. Frequent fires probably lit by the Aboriginal population maintained eucalypts and grasslands in upland northeast Tasmania and prevented expansion of rainforests [73]. The pollen and charcoal record in deep peats on Surrey Hills in northwest Tasmania and on the Nicholas Range in northeast Tasmania provides evidence of fires and fire-induced open eucalypt woodlands being present for at least the last 12000 years [74-76].

We can conclude that many eucalypt forests had a more open character under Aboriginal management than they do at present, and that regular low-intensity fires (mostly burning understorey only) periodically released only modest amounts of $\mathrm{C}$ to the atmosphere. We can be reasonably certain that at least during the Holocene, the Tasmanian lowland and midaltitude vegetation pattern before European arrival was a mosaic of fire-induced forest, rainforest, open woodland, grassland, and sedge-dominated moorlands, a pattern noted by early surveyors such as Lawrence [77] in the Florentine Valley near Maydena and Hellyer [71] in northwest Tasmania, which in part was anthropogenically induced and which, incidentally, makes description of the Tasmanian wet forests as a "wilderness," e.g., "Tasmanian Wilderness World Heritage Area," a misnomer. For a brief period from approximately 1825 (by which time, the Aboriginal population was severely depleted) to 1920 (when mechanised harvest began in earnest), forest cover was neither controlled by frequent Aboriginal land management nor disturbed by clearfelling operations, although timber was extracted from more accessible sites [78]. In this period, for the first time in 12000 years, many forests previously managed by Aboriginal burning grew more densely and regenerated without largescale human intervention, greatly increasing aboveground biomass and fuel for fires.

Possibly partly because of this post-1825 fuel increase and cessation of low-intensity burning, there have been a number of large fires since European settlement in Tasmania. The largest was in 1898 when over 1 million ha and possibly up to 2 million ha of forests in the southwest burned [28]. Other very large fires were in 1934 when 800 000-900 000 ha burned [79] and in 1967 when approximately 250 000 ha burned [80]. Recently, over 2400 recorded lightning strikes in Tasmania in December 2018 and January 2019 caused 72 vegetation fires extending over 205000 ha including c. 100000 ha of wet eucalypt forests and $14 \%$ (296 ha) of Tasmania's tall (>70 m high) eucalypt forests and 7000 ha of rainforest [81]. 


\section{Conclusions}

Previous studies showed that soil $\mathrm{C}$ to $1 \mathrm{~m}$ depth (or a rock contact) under wet eucalypt cover ranged from 35 to $325 \mathrm{Mg} \cdot \mathrm{ha}^{-1}$, depending on stoniness, soil depth, and parent material, but provided little data on soil $\mathrm{C}$ in rainforest soils, so the soil C trend (if any) during the ecological transition of mixed eucalypt forests (mature tall wet eucalypts with a rainforest understorey) to rainforests could not be established.

This study of 7 paired sites found no consistent difference between soil $\mathrm{C}$ stocks under mixed forests or rainforest in Tasmania, and the mean soil $\mathrm{C}$ value under both forest types is about $200 \mathrm{Mg} \cdot \mathrm{ha}^{-1}$. Consequently, at a landscape scale, the loss of biomass C $\left(259 \mathrm{Mg} \cdot \mathrm{ha}^{-1}\right)$ during the transition of mixed eucalypt forests (mean biomass C,

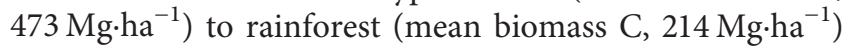
(Table 4) approximates to the total ecosystem loss $\left(269 \mathrm{Mg} \cdot \mathrm{ha}^{-1}\right)$ during this ecological transition (Table 4).

If it is assumed that the transition to rainforest takes 400 years, then the mixed forests are emitting about $0.65 \mathrm{Mg} \cdot \mathrm{ha}^{-1} \mathrm{yr}^{-1}$ until they reach pure rainforest. During this ecological transition, the soils remain (on average) relatively stable: deep soil horizons under rainforest retain an imprint of pyrogenic $\mathrm{C}$ from past fires, and the soils appear to be buffered against the effects of vegetation change and variable $C$ inputs.

The observation that Tasmanian tall wet eucalypt forests become net $\mathrm{C}$ emitters as they mature and transition to rainforests is contrary to trends monitored in northern hemisphere temperate forests in which $\mathrm{C}$ continues to accumulate as forests age [12-14]. It has significant negative implications for land managers expecting $\mathrm{C}$ credits as a result of reserving wet eucalypt forests. Although at a local scale, a young forest will accumulate $\mathrm{C}$, over the long term, and at the landscape scale, there is unlikely to be a net $\mathrm{C}$ benefit from setting aside these forests as reserves: the unmanaged forests will either burn, or they will transition to rainforests containing less $\mathrm{C}$ than the eucalypt forests they replace.

Wetter Tasmanian forests have always consisted of a mosaic of eucalypt age classes and rainforests and more open areas, as a result of natural disturbance (fires and storms) and Aboriginal landscape management [70-76], and we can be confident that they have never consisted of uniform oldgrowth eucalypt forest. It is unlikely that the theoretical maximum percentage cover of $10-15 \%$ tall wet forests (Class 1-3 forests of Moroni et al. [10]) could ever be achieved. As previously argued by Harmon [82], Norris et al. [18], and Poynter and Ryan [83], maintaining a mosaic of managed native production forests, including regenerating eucalypts, mixed forests, rainforests, and reserves for biodiversity, soil and water, and cultural values, and also for recreational use, while at the same time ensuring good access to facilitate wildfire control, is likely to be the best strategy for maintaining landscape $\mathrm{C}$ stocks in the long term.

\section{Data Availability}

The survey data on which this study is based are available in the theses by Hardcastle [47] and Klöffel [48]. Calculations of C stocks from the soil data of Grant et al. [21], Hill et al. [22], and Laffan et al. [23] are available as an excel spreadsheet from the corresponding author.

\section{Disclosure}

This paper is partly based on the unpublished research theses of J. Hardcastle and T. Klöffel.

\section{Conflicts of Interest}

None of the authors have conflicts of interest regarding the conduct of this study or the interpretation of its results.

\section{Acknowledgments}

The authors are grateful to Elizabeth Brewer, Adrian Slee, and Carsten Müller who assisted with fieldwork, Peter Schad for checking FAO soil classifications, and Carsten Müller, Mark Poynter, and two anonymous reviewers for their valuable comments on drafts of the text. The Board of the Forest Practices Authority provided funds to support the research and travel costs of James Hardcastle, Tobias Klöffel, and Carsten Müller. The authors thank Sustainable Timber Tasmania and the Department of Primary Industries, Parks, Water, and the Environment for allowing access to sites.

\section{References}

[1] R. A. Houghton, "Balancing the global carbon budget," Annual Review of Earth and Planetary Sciences, vol. 35, no. 1, pp. 313-347, 2007.

[2] R. K. Dixon, S. Brown, R. A. Houghton et al., "Carbon pools and flux of global forest ecosystems," Science, vol. 263, no. 5144, pp. 185-190, 1994.

[3] Y. Mahli, D. D. Baldocchi, and P. G. Jarvis, "The carbon balance of tropical, temperate and boreal forests," Plant, Cell and Environment, vol. 22, pp. 715-740, 1999.

[4] R. Lal and K. Lorenz, "Carbon sequestration in temperate forests. Chapter 9," in Recarbonisation of the Biosphere, R. Lal, K. Lorenz, R. F. Hüttl, B. U. Schneider, and J. von Braun, Eds., Springer, Berlin, Germany, 2012.

[5] W. G. Sombroek, F. O. Nachtergaele, and A. Hebel, "Amounts, dynamics and sequestering of carbon in tropical and subtropical soils," Ambio, vol. 22, pp. 417-426, 1993.

[6] H. Keith, B. G. Mackey, and D. B. Lindenmayer, "Re-evaluation of forest biomass carbon stocks and lessons from the world's most carbon-dense forests," Proceedings of the $\mathrm{Na}$ tional Academy of Sciences, vol. 106, no. 28, pp. 11635-11640, 2009.

[7] P. Grierson, M. Adams, and P. Attiwill, "Estimates of carbon storage in the aboveground biomass of victorias forests," Australian Journal of Botany, vol. 40, no. 5, pp. 631-640, 1992.

[8] IPCC, Land Use, Land-Use Change, and Forestry, R. T. Watson, I. R. Noble, B. Bolin et al., Eds., Cambridge University Press, Cambridge, UK, 2000.

[9] S. C. Sillett, R. Van Pelt, R. D. Kramer, A. L. Carroll, and G. W. Koch, "Biomass and growth potential of Eucalyptus regnans up to $100 \mathrm{~m}$ tall," Forest Ecology and Management, vol. 348, pp. 78-91, 2015.

[10] M. T. Moroni, T. H. Kelley, and M. L. McLarin, "Carbon in trees in Tasmanian state forest," International Journal of Forestry Research, vol. 2010, pp. 1-13, 2010. 
[11] M. T. Moroni, R. Musk, and T. J. Wardlaw, "Forest succession where trees become smaller and wood carbon stocks reduce," Forest Ecology and Management, vol. 393, pp. 74-80, 2017.

[12] A. R. Desai, P. V. Bolstad, B. D. Cook, K. J. Davis, and E. V. Carey, "Comparing net ecosystem exchange of carbon dioxide between an old-growth and mature forest in the upper Midwest, USA," Agricultural and Forest Meteorology, vol. 128, no. 1-2, pp. 33-55, 2005.

[13] D. M. Kashian, W. H. Romme, D. B. Tinker, M. G. Turner, and M. G. Ryan, "Postfire changes in forest carbon storage over a 300-year chronosequence of Pinus contorta-dominated forests," Ecological Monographs, vol. 83, no. 1, pp. 49-66, 2013.

[14] S. Luyssaert, E. D. Schulze, A. Börner et al., "Old-growth forests as global carbon sinks," Nature, vol. 455, no. 7210, pp. 213-215, 2008.

[15] B. G. Mackey, H. Keith, and D. Lindenmayer, "Green Carbon, the role of natural forests in carbon storage," Contract Report for the Wilderness Society, ANU, Canberra, Australia, 2008.

[16] J. N. Gilbert, "Forest succession in the Florentine Valley, Tasmania," Papers and Proceedings of the Royal Society of Tasmania, vol. 93, pp. 129-151, 1959.

[17] W. D. Jackson, "Fire, air, water and earth-an elemental ecology of Tasmania," Proceedings of the Ecological Society of Australia, vol. 3, pp. 9-16, 1968.

[18] J. Norris, S. Arnold, and T. Fairman, "An indicative estimate of carbon stocks on Victoria's publicly managed land using the FullCAM carbon accounting model," Australian Forestry, vol. 73, no. 4, pp. 209-219, 2010.

[19] S. J. Krishnaraj, "Effects of fire on soil organic carbon dynamics in eucalyptus forests of South-Eastern Australia," http://hdl.handle.net/11343/40982Thesis, University of Melbourne, Melbourne, Australia, 2014, http://hdl.handle.net/ 11343/40982Thesis.

[20] M. W. Jones, C. Santín, G. R. van der Werf, and S. H. Doerr, "Global fire emissions buffered by the production of pyrogenic carbon," Nature Geoscience, vol. 12, no. 9, pp. 742-747, 2019.

[21] J. C. Grant, M. D. Laffan, and R. C. Hill, Soils of Tasmanian State Forests 2. Forester Sheet. Soils Bulletin 2, Forestry Tasmania, Hobart, Australia, 1995.

[22] R. Hill, M. D. Laffan, and J. Grant, Soils of Tasmanian State Forests 3. Forth Sheet. Soils Bulletin 3, Forestry Tasmania, Hobart, Australia, 1995.

[23] M. Laffan, J. Grant, and R. Hill, Soils of Tasmanian State Forests 1. Pipers Sheet. Soils Bulletin 1, Forestry Tasmania, Hobart, Australia, 1995.

[24] P. D. McIntosh, "Soil characterisation at the Warra Flux Tower Supersite. Version 2, with supplementary data," Forest ntract Report, Prepared for Forestry Tasmania, Forest Practices Authority, Hobart, Australia, 2012.

[25] P. D. McIntosh, M. Laffan, and A. Hewitt, "The role of fire and nutrient loss in the genesis of the forest soils of Tasmania and southern New Zealand," Forest Ecology and Management, vol. 220, pp. 185-215, 2003.

[26] S. Duarte-Guardia, P. L. Peri, W. Amelung et al., "Better estimates of soil carbon from geographical data: a revised global approach," Mitigation and Adaptation Strategies for Global Change, vol. 24, no. 3, pp. 355-372, 2019.

[27] C. Dean and G. Wardell-Johnson, "Old-growth forests, carbon and climate change: functions and management for tall open-forests in two hotspots of temperate Australia," Plant Biosystems-An International Journal Dealing with All Aspects of Plant Biology, vol. 144, no. 1, pp. 180-193, 2010.
[28] B. May, J. Bulinski, A. Goodwin, and S. Macleod, "Tasmanian Forest carbon study," Report for the Tasmanian State Government, CO2 Australia Ltd, West End, Australia, 2012.

[29] P. D. McIntosh and M. Moroni, "Carbon sequestration in Tasmania's forests, perceptions, misrepresentations and ecological reality," in Proceedings of the Australian Forest Growers' Conference, Launceston, Australia, October 2016.

[30] M. Fedrigo, S. Kasel, L. T. Bennett, S. H. Roxburgh, and C. R. Nitschke, "Carbon stocks in temperate forests of southeastern Australia reflect large tree distribution and edaphic conditions," Forest Ecology and Management, vol. 334, pp. 129-143, 2014.

[31] BOM (Bureau of Meteorology), "Climate statistics for Australian sites," 2020, http://www.bom.gov.au/climate/averages/ tables/ca_tas_names.shtml.

[32] M. Nunez, "A regional lapse rate for Tasmania," Papers and Proceedings of The Royal Society of Tasmania, vol. 122, no. 2, pp. 53-57, 1988.

[33] FAO, "World reference base for Soil resources, 2014. International soil classification system for naming soils and creating legends for soil maps," World Soil Resources Reports No. 106, FAO, Rome, Italy, 2014.

[34] R. Mäkipää, J. Kiski, S. Guendehou et al., "Soil carbon monitoring using surveys and modelling. general description and application in the United Republic of Tanzania," FAO, Rome, Italy, FAO Forestry Paper 168, 2012.

[35] P. Muukkonen, M. Häkkinen, and R. Mäkipää, "Spatial variation in soil carbon in the organic layer of managed boreal forest soil-implications for sampling design," Environmental Monitoring and Assessment, vol. 158, no. 1-4, pp. 67-76, 2009.

[36] S. C. Cunningham, S. H. Roxburgh, K. I. Paul, A. F. Patti, and T. R. Cavagnaro, "Generating spatially and statistically representative maps of environmental variables to test the efficiency of alternative sampling protocols," Agriculture, Ecosystems \& Environment, vol. 243, pp. 103-113, 2017.

[37] B. Murphy, A. Rawson, L. Ravenscroft, M. Rankin, and R. Millard, "Paired site sampling for soil carbon estimation-New South Wales," Technical Report 34, National Carbon Accounting System, Canberra, Australia, 2003.

[38] N. McKenzie, P. Ryan, P. Fogarty, and J. Wood, "Sampling, measurement and analytical protocols for carbon estimation in soil, litter and coarse woody debris," National Carbon Accounting System Technical Report No. 14, Australian Greenhouse Office, Canberra, Australia, 2000, http://www.greenhouse.gov.au/ncas/ files/consultancies/soilchange/soils.html.

[39] R. A. Viscarra Rossel, R. Webster, E. N. Bui, and J. A. Baldock, "Baseline map of organic carbon in Australian soil to support national carbon accounting and monitoring under climate change," Global Change Biology, vol. 20, no. 9, pp. 2953-2970, 2014.

[40] Soil Survey Team, Field Guide for Sampling and Describing Soils in the Papua New Guinea National Forest Inventory, Forest Research Institute, Papua New Guinea Forest Authority, Lae, Papua New Guinea, 2019.

[41] P. D. McIntosh, A. E. Hewitt, K. Giddens, and M. D. Taylor, "Benchmark sites for assessing the chemical impacts of pastoral farming on loessial soils in southern New Zealand," Agriculture, Ecosystems \& Environment, vol. 65, no. 3, pp. 267-280, 1997.

[42] A. Ghani, M. Dexter, and K. W. Perrott, "Hot-water extractable carbon in soils: a sensitive measurement for determining impacts of fertilisation, grazing and cultivation," Soil Biology and Biochemistry, vol. 35, no. 9, pp. 1231-1243, 2003. 
[43] I. Kögel-Knabner, "The macromolecular organic composition of plant and microbial residues as inputs to soil organic matter," Soil Biology and Biochemistry, vol. 34, no. 2, pp. 139-162, 2002.

[44] R. J. Smernik and J. M. Oades, "Effects of added paramagnetic ions on the CP/MAS NMR spectrum of a de-ashed soil," Geoderma, vol. 89, no. 3-4, pp. 219-248, 1999.

[45] I. Kögel-Knabner, G. Guggenberger, M. Kleber et al., "Organomineral associations in temperate soils: integrating biology, mineralogy, and organic matter chemistry," Journal of Plant Nutrition and Soil Science, vol. 171, no. 1, pp. 61-82, 2008.

[46] M. J. Gardner and D. G. Altman, "Confidence intervals rather than p values: estimation rather than hypothesis testing," $B M J$, vol. 292, no. 6522, pp. 746-750, 1986.

[47] J. Ho, T. Tumkaya, S. Aryal, H. Choi, and A. Claridge-Chang, "Moving beyond p values: data analysis with estimation graphics," Nature Methods, vol. 16, no. 7, pp. 565-566, 2019.

[48] J. L. Hardcastle, "Changes in carbon and other soil properties with succession of mixed forests to rainforests in Tasmania," Unpublished thesis, University of Queensland, Brisbane, Australia, 2018.

[49] T. Klöffel, "Comparison of soil organic matter quality under wet eucalypt and old-growth rainforests in Tasmania," Unpublished thesis, Technical University of Munich, Munich, Germany, 2019.

[50] W. E. Cotching, "Carbon stocks in Tasmanian soils," Soil Research, vol. 50, no. 2, pp. 83-90, 2012.

[51] P. Snowden, D. Eamus, P. Gibbons et al., "Synthesis of Allometrics, review of root biomass and design of future woody biomass sampling strategies," Technical Report 17, National Carbon Accounting System, Canberra, Australia, 2000.

[52] IPCC (Intergovernmental Panel on Climate Change), Revised 1996 IPCC Guidelines for National Greenhouse Gas Inventories: Reference Manual, IPCC, Geneva, Switzerland, 1996.

[53] National Committee on Soil and Terrain, Australian Soil and Land Survey Field Handbook, CSIRO, Collingwood, UK, 3rd edition, 2009.

[54] G. Angst, K. E. Mueller, D. M. Eissenstat et al., "Soil organic carbon stability in forests: distinct effects of tree species identity and traits," Global Change Biology, vol. 25, no. 4, pp. 1529-1546, 2019.

[55] A. C. von Haden, C. J. Kucharik, R. D. Jackson, and E. MarínSpiotta, "Litter quantity, litter chemistry, and soil texture control changes in soil organic carbon fractions under bioenergy cropping systems of the North Central U.S," Biogeochemistry, vol. 143, no. 3, pp. 313-326, 2019.

[56] J. Skjemstad, P. Clarke, J. Taylor, J. Oades, and S. McClure, "The chemistry and nature of protected carbon in soil," Soil Research, vol. 34, no. 2, pp. 251-271, 1996.

[57] J. Skjemstad, P. Clarke, A. Golchin, and J. Oades, "Characterization of soil organic matter by solid-state ${ }^{13} \mathrm{C} N M R$ spectroscopy," in Driven by Nature. Plant Litter Quality and Decomposition, G. Cadisch and K. Giller, Eds., pp. 253-267, CAB International, London, UK, 1997.

[58] P. J. Edwards and P. J. Grubb, "Studies of mineral cycling in a Montane Rain forest in new Guinea: I. The distribution of organic matter in the vegetation and soil," The Journal of Ecology, vol. 65, no. 3, pp. 943-969, 1977.

[59] D. W. Johnson and P. S. Curtis, "Effects of forest management on soil C and N storage: meta analysis," Forest Ecology and Management, vol. 140, no. 2-3, pp. 227-238, 2001.

[60] P. Pennington, M. Laffan, R. Lewis, and P. Otahal, "Assessing the long-term impacts of forest harvesting and high intensity broadcast burning on soil properties at the Warra LTER site," Tasforests, vol. 13, pp. 291-301, 2001.

[61] A. Slijepcevic, "Loss of carbon during controlled regeneration burns in Eucalyptus forest," Tasforests, vol. 13, pp. 281-290, 2001.

[62] R. C. Ellis and A. M. Graley, "Gains and losses in soil nutrients associated with harvesting and burning eucalypt rainforest," Plant and Soil, vol. 74, no. 3, pp. 437-450, 1983.

[63] P. J. Polglase, M. A. Adams, and P. M. Attiwill, Measurement and Modelling of Carbon Storage in a Chronosequence of Mountain Ash Forests, Implications for Regional and Global Carbon Budgets, State Electricity Commission, Victoria, Australia, 1994.

[64] D. F. Guinto, Z. H. Xu, A. P. N. House, and P. G. Saffigna, "Soil chemical properties and forest floor nutrients under repeated prescribed burning in eucalypt forests of south-east Queensland, Australia," New Zealand Journal of Forest Science, vol. 31, pp. 170-187, 2001.

[65] C. Dean, S. Roxburgh, and B. G. Mackey, "Forecasting landscape-level carbon sequestration using gridded, spatially adjusted tree growth," Forest Ecology and Management, vol. 194, no. 1-3, pp. 109-129, 2004.

[66] H. Keith, B. Mackey, S. Berry, and D. Lindenmayer, "Estimating carbon carrying capacity in natural forest ecosystems across heterogeneous landscapes, addressing sources of error," Global Change Biology, vol. 16, pp. 2971-2989, 2010.

[67] M. T. Moroni, T. H. Kelley, M. L. McLarin, and S. M. Read, "The wood, the trees, or the forest? Carbon in trees in Tasmanian state forest: a response to comments," International Journal of Forestry Research, vol. 2012, no. 4, pp. 1-6, 2012.

[68] R. K. Gupta and D. L. N. Rao, "Potential of wastelands for sequestering carbon by forestation," Current Science, vol. 66, pp. 378-380, 1994.

[69] R. Jones, "Fire-stick farming," Australian Natural History, vol. 16, pp. 224-228, 1969.

[70] W. Gammage, The Biggest Estate on Earth, Allen \& Unwin, Crows Nest, Australia, 2011.

[71] H. Hellyer, Map of Surrey Hills. Private Collection, Forico Ltd, Kings Meadows, Australia, 1827.

[72] R. Onfray, "Cultural artefacts or 'neglected old parks', the colonisation of rainforests in north-western Tasmania. Chapter 7," in Australia's Ever-Changing Forests VI: Proceedings of the Eighth National Conference on Australian Forest History, B. J. Stubbs, Ed., Australian Forest History Society, Kingston, Australia, 2012.

[73] R. C. Ellis, "The relationships among eucalypt forest, grassland and rainforest in a highland area in north-eastern Tasmania," Austral Ecology, vol. 10, no. 3, pp. 297-314, 1985.

[74] E. Watson, "Holocene environments of Surrey Hills, Northern Tasmania," Honours thesis, University of Queensland, Brisbane, Australia, 2013.

[75] P. D. McIntosh, P. Moss, E. Watson, and R. Onfray, "Aboriginal vegetation management in northwest Tasmania, When did it begin?," in Culture Climate Change, Archaeology in the Tropics, Conference Handbook, S. Ulm, G. Mate, and J. Jerbic, Eds., p. 120, Australian Archaeology Association, Cairns, Australia, 2014.

[76] O. Moss, A. Farrell, J. Vink, P. McIntosh, and A. Slee, "Last Glacial and deglacial environments of sub-alpine Tasmania," in Proceedings of the Papers Presented at, INQUA Conference, Dublin, Ireland, July 2019. 
[77] A. G. S. Lawrence, Map of the Florentine Valley. Registered Plan Number 308, Forestry Department, Tasmania, Hobart, Australia, 1923.

[78] P. Kostoglou, "Historic timber-getting in the southern forests. Industry overview and assessment of its technology," Archaeology of the Tasmanian Timber Industry, Report No. 8, Forestry Tasmania and Tasmanian Forest Research Council, Hobart, Australia, 1996.

[79] J. Marsden-Smedley, "Changes in southwestern Tasmanian fire regimes since the early 1800s," Papers and Proceedings of the Royal Society of Tasmania, vol. 132, pp. 15-29, 1998.

[80] B. Walker and K. Felton, "Section 4: Tasmania," in Forest management in Australia: Implications for Carbon Budgets. National Carbon Accounting System Technical Report 32, R. J. Raison and R. O. Squire, Eds., pp. 47-192, National Carbon Accounting System, Canberra, Australia, 2007.

[81] M. Cronstedt, G. Thomas, and P. Considine, "A review of the management of the Tasmanian Fires of December 2018-March 2019," Australasian Fire and Emergency Service Authorities Council (AFAC) Report, AFAC, East Melbourne, Australia, 2019.

[82] M. E. Harmon, "Carbon sequestration in forests, addressing the scale question," Journal of Forestry, vol. 99, pp. 24-29, 2001.

[83] M. Poynter and M. Ryan, "Leadbeater's possum and Victoria's Central Highlands' forests: flawed science and environmental activism as drivers of forest management change," Australian Forestry, vol. 81, no. 4, pp. 250-272, 2018. 